NBER WORKING PAPER SERIES

\title{
NET FISCAL STIMULUS DURING THE GREAT RECESSION
}

\author{
Joshua Aizenman \\ Gurnain Kaur Pasricha \\ Working Paper 16779 \\ http://www.nber.org/papers/w16779
NATIONAL BUREAU OF ECONOMIC RESEARCH
1050 Massachusetts Avenue
Cambridge, MA 02138
February 2011

We would like to thank Kristina Hess for outstanding research assistance. We also thank Daniel Wilson, Robert Lavigne and conference participants at the American Economic Association Annual Meeting in Denver, January 2011 for comments. The views expressed in the paper are those of the authors. No responsibility for them should be attributed to the Bank of Canada or to the National Bureau of Economic Research.

NBER working papers are circulated for discussion and comment purposes. They have not been peerreviewed or been subject to the review by the NBER Board of Directors that accompanies official NBER publications.

(C) 2011 by Joshua Aizenman and Gurnain Kaur Pasricha. All rights reserved. Short sections of text, not to exceed two paragraphs, may be quoted without explicit permission provided that full credit, including ( $)$ notice, is given to the source. 
Net Fiscal Stimulus During the Great Recession

Joshua Aizenman and Gurnain Kaur Pasricha

NBER Working Paper No. 16779

February 2011

JEL No. E62,F36,H77

\begin{abstract}
$\underline{\text { ABSTRACT }}$
This paper studies the patterns of fiscal stimuli in the OECD countries propagated by the global crisis. Overall, we find that the USA net fiscal stimulus was modest relative to peers, despite it being the epicenter of the crisis, and having access to relatively cheap funding of its twin deficits. The USA is ranked at the bottom third in terms of the rate of expansion of the consolidated government consumption and investment of the 28 countries in sample. Contrary to historical experience, emerging markets had strongly countercyclical policy during the period immediately preceding the Great Recession and the Great Recession. Many developed OECD countries had procyclical fiscal policy stance in the same periods. Federal unions, emerging markets and countries with very high GDP growth during the pre-recession period saw larger net fiscal stimulus on average than their counterparts. We also find that greater net fiscal stimulus was associated with lower flow costs of general government debt in the same or subsequent period.
\end{abstract}

Joshua Aizenman

Department of Economics; E2

1156 High St.

University of California, Santa Cruz

Santa Cruz, CA 95064

and NBER

jaizen@ucsc.edu

Gurnain Kaur Pasricha

Bank of Canada

234 Wellington Street

Ottawa, ON K1A 0G9

Canada

gpasricha@bankofcanada.ca 


\section{Introduction}

In the wake of the global crisis of 2008-9 there has been an intense debate about the efficacy of fiscal policy and the size of the fiscal multipliers (Ilzetzki et al., 2010 and the references therein). This paper takes a positive perspective on these issues by focussing on measuring and comparing the size of the net fiscal stimuli across countries. The impact of a given increase in government spending (G) on GDP equals the fiscal multiplier times the net fiscal stimulus, i.e.,

$\triangle G D P=$ Fiscal Multiplier $* \Delta G$. While much of the debate has focussed on the size of fiscal multipliers, having a measure of the magnitude of fiscal stimuli enacted is a necessary condition for understanding the impact of fiscal policy.

With this premise, we investigate a host of important positive questions associated with fiscal stimuli during the Great Recession. First and foremost, we ask which OECD countries had the largest fiscal stimuli during the Great Recession and which countries simulated least. We ask whether the USA, a country that was the epicenter of the crisis, and a country that has enjoyed the exorbitant privilege (i.e., relatively easy funding of its fiscal and current account deficits), engaged in larger fiscal stimuli than other countries. Second, taking the benchmark of the previous literature regarding the historical procyclicality of fiscal policy in developing countries, and countercyclicality of fiscal stance in the OECD countries (Kaminsky et al., 2004 and the reference therein), we rank countries by the revealed countercyclicality of their fiscal stimuli during the Great Recession. We ask whether we observed the old patterns of procyclically fiscal policy in developing countries during the Great Recession. Other questions we explore in this paper include: did the federal structure of a country matter for the net fiscal stimulus? What is the association between the fiscal stimuli and the flow costs of servicing the public debt? What explained the net fiscal stimulus at the consolidated level - federal or state spending? Did the response of state spending to GDP growth differ in the Great Recession from previous recessions?

To answer these questions about the size of the fiscal stimulus during the Great Recession, we use quarterly data on the pure fiscal expenditures of the consolidated government, the central government and the state and local governments for OECD countries. Pure fiscal expenditure is the real consumption and investment expenditure $\left(C_{g}+I_{g}\right)$ at any level of government. It is the 
' $G$ ' or the consolidated government expenditure in the national income identity, which is relevant for computing the neo-Keynesian fiscal multiplier. We refer to increases in $G$ as 'net fiscal stimulus'. It is important to remember that the ' $G$ ' in the national income identity does not include transfers - unemployment benefits, financial bailouts, etc. - and therefore these are excluded from this study.

OECD members include some countries that are also considered emerging markets, like Korea, Mexico, Chile and Turkey. Some OECD members are federal unions or 'federations', i.e., they have a constitutionally guaranteed separation of powers between the center and the regional governments, like the USA, Canada, Australia, etc, while others are non-federal unions. ${ }^{1}$ This heterogeneity allows us to look at differences between different groups of countries. We are particularly interested in comparing federations with non-federations because in Aizenman and Pasricha (2010), where we looked at pure fiscal expenditures in USA alone, we conjectured that the moral hazard concerns in a federal union may provide one explanation for the lack of a large fiscal stimulus there.

The results provide mixed, complex and somehow surprising mapping of these issues. Overall, we find that the net fiscal stimulus in the USA was modest at best, despite the country having being the epicenter of the crisis, and having access to relatively cheap funding of its twin deficits. The USA is ranked at the bottom third in terms of the rate of expansion of the consolidated government consumption and investment of the 28 countries in sample, well below the largest spenders, i.e., Portugal, Australia, Mexico, Korea, Chile and Canada. Contrary to historical experience, emerging markets had strongly countercyclical policy during the period immediately preceding the Great Recession and the Great Recession. Many non-emerging OECD countries had procyclical fiscal policy stance in the same periods. Contrary to the US experience, federal unions on average saw larger net fiscal stimulus than their counterparts. We also find that greater net fiscal stimulus was associated with lower flow costs of general government debt in the same or subsequent period, contradicting the view that markets penalized countries that expanded spending during the Great Recession.

\footnotetext{
${ }^{1}$ The list of federations is from Treisman (2000). Spain is excluded as although it is a de-facto federation, it is not a constitutional one. See Table 1 for a list of countries in sample and their classification into different groups.
} 


\section{Data}

Our sample consists of all OECD countries for which quarterly data on pure fiscal expenditures for the consolidated government $(G)$ or its components was available. The list of countries and the beginning and end dates for which quarterly data on $G$ was available are in Table 1 . The table also lists whether the country falls in any of the three groups - Federation, Emerging Market Economy (EME) or European Monetary Union (EMU). There are 7 emerging markets and 7 federations in the sample. Data for all countries ends in 2010Q1 or 2010Q2. The longest available series is for the United Kingdom, for which data since 1955 is available, and the shortest series is for Chile, starting in 2004. We also have data on pure fiscal expenditures of central government $\left(G^{c}=C_{g}^{c}+I_{g}^{c}\right)$ and state and local governments $\left(G^{S}=C_{g}^{s}+I_{g}^{s}\right)$ for six countries, Australia, Iceland, Norway, Sweden, United Kingdom and USA.

All data are in real terms, seasonally adjusted, and at annual rates. The data was collected from national sources and Thomson Financial's Datastream, IMF's International Financial Statistics, OECD Stat, EuroStat and DataInsight. For countries for which non-seasonally adjusted data was available from the source, the $G, G^{c}$ and $G^{s}$ series were adjusted for seasonality using Census X12 method. As far as possible, the seasonal adjustment was done after converting the series to real terms. For conversion into real terms, where possible, series specific deflators were used (e.g.: government consumption deflator for government consumption series and government GFCF deflator for government investment series). When separate consumption and investment deflators for each level of government were not available, government consumption or government expenditure deflators for the same level of government were used to deflate the pure fiscal expenditures at each level of government. For the central and state level data, general government deflators were used if that was the only series available. Finally, for countries for which none of the government expenditure specific price deflators were available, the GDP deflator was used to convert the $G, G^{c}$ and $G^{S}$ series to real terms.

The NBER dated the most recent recession in the USA (also referred to as the Great Recession) from 2007Q4 to 2009Q2. However, due to lags in policy formulation and implementation, we measure the fiscal stimulus over the entire period since 2007Q4 over which we have data, i.e. 2007Q4-2010Q1. We also split the period into two: 2007Q4-2008Q4, and 
2009Q1 to 2010Q1. The changes in pure fiscal expenditures during the latter period are more likely to reflect the policy response to the recession.

We use the data on pure fiscal expenditures to address 5 questions:

1. Which countries delivered a large net fiscal stimulus during the Great Recession? How did the growth of the pure fiscal expenditure during this period compare to its growth and to GDP growth during the pre-crisis period?

2. Was the average fiscal stimulus different between emerging markets, federal unions, EMU countries and their counterparts?

3. To what extent was fiscal policy at the consolidated government level countercyclical, in the cycle consisting of the expansionary phase pre-2007 and the contractionary phase since?

4. How was the net fiscal stimulus associated with the flow cost of public debt faced by countries?

5. What drove the net fiscal stimulus at the consolidated level - federal or state spending? Did the response of state spending to GDP growth differ in the Great Recession from previous recessions?

\section{On the size of the net fiscal stimulus across countries}

Portugal, Australia, Mexico, Korea, Chile and Canada saw the fastest growth in G over the period 2009Q1-2010Q1, whereas Greece, Iceland, Ireland, Poland, Austria and Italy saw a contraction of G over the same period. The USA saw the $9^{\text {th }}$ lowest rate of expansion of $G$ of the 28 countries in sample. Moreover, in nine countries - Austria, Czech Republic, Greece, Ireland, Iceland, Italy, Poland, Turkey and USA - the average growth of G during 2009Q1-2010Q1 was lower than the mean GDP growth during pre-crisis period by more than one standard deviation.

To compare the size of the net fiscal stimuli across countries, we look at the growth rates of consolidated government real consumption and investment expenditures over the Great Recession and its sub-periods. We compare this growth across countries and for each country over time. 
Figure 1 plots the growth rates of each country's $G$ over the period 2007Q4-2008Q4 and 2009Q1-2010Q1. The growth rate used in the figure is the compound annual growth rate (CAGR). A CAGR of $x \%$ between 2007Q4-2008Q4 implies that if the $G$ during 2007Q3 grew at a constant rate of $x \%$ compounded annually over the next five quarters, it would reach the level that it was in 2008Q4. It applies a constant annual rate of growth over each year in the period, to the value at the beginning of the period. The reason for using CAGR, rather than an average of quarterly growth rates is that such an average does not tell us whether the $G$ at the end of the period was higher or lower than the $G$ at the beginning of the period. ${ }^{2}$ The average of quarter-onquarter (QoQ) growth rates can be positive even if the value at the end of the period is lower than the value in beginning of the period.

Due to lags in formulation and implementation of fiscal policy, we consider the latter period, 2009Q1-2010Q1 as the period in which one would expect to see in the data, a policy driven response to the crisis. Accordingly, the countries in Figure 1 are ranked based on their net fiscal stimulus during the period 2009Q1-2010Q1. Of the 28 countries in the figure, the six countries on the extreme left saw a decline in $G$ over the period 2009Q1-2010Q1. These 6 include the countries that had or have since had sovereign debt crises in this period - Greece, Iceland and Ireland - but also Poland, Austria and Italy. Greece had the largest negative net stimulus over this period, with a contraction of $G$ at a rate of 15.8 percent per annum.

Twenty two out of the twenty eight countries in Figure 1 saw a positive growth of $G$ during 2009Q1-2010Q1, i.e. the $G$ in each of these countries was higher in 2010Q1 than it was in 2008Q4. At the far right in the figure are the countries that had the highest net fiscal stimuli. These were: Portugal, Australia, Mexico, Korea, Chile and Canada. Three out of the 5 largest stimuli were in emerging economies. Growth rates of $G$ in Portugal, Australia, Mexico and Korea averaged close to 10 percent per annum over this period.

The USA, which saw the worst recession since the Great Depression is ranked $9^{\text {th }}$ from the bottom. Its $G$ grew at a compound annual rate of only 0.31 percent over 2009Q1-2010Q1. Germany had a growth of $G$ over the same period that was almost 10 times as large, at 2.81

2 The CAGR is computed as $\left(\frac{\text { Ending Value }}{\text { Beginning Value }}\right)^{\left(\frac{4}{\text { Number of Quarters }}\right)}-1$ and expressed as a percentage. When measured over 4 quarters, this would be the same as percentage change over the 4 quarters. Here, the value is measured over 5 quarters, so using the CAGR rather than the percentage change allows express the rate of change as percent per annum. 
percent. In many countries in the figure, including all that had a negative net fiscal stimulus in the period 2009Q1-2010Q1, and also including the USA, the discretionary response to the recession seemed to involve a curtailment in the growth of $G$, as the growth rate of $G$ during 2007Q4-2008Q4 is higher than the growth rate over 2009Q1-2010Q1. However in other countries, for example, Hungary, Portugal, Korea, Australia, Canada, Japan and Denmark, the net fiscal stimulus during 2009Q1-2010Q1 involved a reversal of the decline in $G$ over the previous period, or an increase in its rate of growth.

The figure underscores the fact that the fiscal response to the Great Recession differed greatly across the OECD countries. The net fiscal stimulus during 2009Q1-2010Q1 varied from -16 percent in Greece to 12 percent in Portugal. Out of twenty eight OECD countries, 16 countries saw their growth rate of $G$ decline in the second half of the Great Recession period and 10 countries had growth gates of $G$ close to zero (including the USA). Just as the expansion in fiscal spending during the recession was not uniform across countries, the need for consolidation after the recession also varies, and fiscal retrenchment everywhere post-crisis may be unwarranted.

Next, we compare the growth of $G$ in each country during the Great Recession quarters with its growth and with GDP growth in the period immediately preceding the Great Recession. Using the standard deviation of quarterly growth rates, we construct confidence intervals around the average growth rates during the pre-Great Recession period for each country. If the average growth rate of $G$ during the Great Recession lies above these confidence intervals, it indicates a large stimulus push during the Great Recession, and vice versa.

In table 2, we construct confidence intervals for the average quarterly growth of $G$, based on the mean and standard deviation of the quarterly growth rates of $G$ during the period 2004Q12007Q1. Only two countries, Australia and Canada, saw an average quarterly growth of $G$ during 2009Q1-2010Q1 that was more than one standard deviation higher than the average growth during the pre-crisis period. For the USA, the growth during 2007Q4-2008Q4 was more than one standard deviation higher than the average growth during the pre-crisis period, but during the 2009Q1-2010Q1, the average quarterly growth rate slowed to 0.31 percent per annum, lower than the average growth during 2004Q1-2007Q1 of 0.81 percent per annum. Greece, Iceland and Austria had negative growth rates of $G$ that were more than one standard deviation lower than the average growth rates during the pre-crisis period. 
In table 3, we construct the confidence intervals based on the pre-crisis GDP growth. If the GDP had continued to grow at the pace it was growing at in the pre-crisis period, keeping the growth of $G$ within these confidence intervals would have kept the expected size of the government stable with respect to GDP. Five countries - Australia, Canada, Chile, Korea and Portugal - had an average QoQ growth of $G$ during 2009Q1-2010Q1 that was more than one standard deviation higher than the average GDP growth in the pre-recession period, indicating an effective stimulus effort in these countries. On the other hand, in nine countries - Austria, Czech Republic, Greece, Ireland, Iceland, Italy, Poland, Turkey and USA - the average growth of $G$ during 2009Q1-2010Q1 was lower than the mean GDP growth during pre-crisis period by more than one standard deviation.

These tables suggest that the growth rate of $G$ during the Great Recession were significantly larger than in the pre-recession period in only a handful of countries, and in fact did not exceed the trend they would have followed had the government tried to stabilize the G/GDP ratios with the expectation that the pre-crisis GDP growth would continue.

\section{Net fiscal stimulus across groups of countries}

Federal unions, emerging markets and countries with very high GDP growth during the pre-recession period saw larger net fiscal stimulus on average than their counterparts.

In order to better understand whether countries that shared certain characteristics were more likely to deliver a large net fiscal stimulus, we look at the average fiscal stimulus across different groups of countries. We consider 6 groups of countries:

1. Federal Unions vs. Non-Federal Unions

2. European Monetary Union (EMU) countries vs. non-EMU countries

3. Federal Unions in EMU vs. Federal Unions not in EMU

4. Emerging Market Economies (EME) vs. Non Emerging Markets

5. High Growth vs. Moderate Growth countries. High growth countries are those that had an average QoQ growth rate of GDP per capita during the period 2004Q12007Q1 in the top 25 percent of such growth rates for all countries in sample. Low growth countries are those that had an average QoQ growth of GDP per 
capita in the bottom 25 percent of GDP growth rates during the same period, and all countries between $25^{\text {th }}$ and $75^{\text {th }}$ percentiles are in the moderate growth countries group. The list of countries included in each group is in appendix table A1.

6. Low Growth vs. Moderate Growth countries.

Figure 1 compares the relative average QoQ growth of $G$ over these groups. The figure shows that in federal unions, the average growth in $G$ during the pre-recession period, 2004Q12007Q1 was lower than in non-federal unions, but during the recession period, 2007Q4-2010Q1, the average growth rate of $G$ in federal unions was about twice that in non-federal unions. This suggests that a federalist structure by itself was not an impediment to a large net fiscal stimulus.

EMU countries had a rapid increase in $G$ in the pre-recession period, with average quarterly growth rates over twice the average growth in non-EMU countries, but during the recession period, their average growth in $G$ was less than half the size of the average growth in non-EMU countries. The same pattern holds if one compares only the federal unions amongst EMU countries against non-EMU federal unions. This suggests that EMU countries - whether federal unions or not - were relatively fiscally profligate in the pre-recession period, (and perhaps as a result) more conservative during the Great Recession period.

Emerging economies, on the other hand, saw relatively slower growth of pre fiscal expenditures at the consolidated government level in the pre-crisis period, despite having higher GDP growth rates in this period. Perhaps this fiscal restraint in the good times allowed them to deliver a substantially larger net fiscal stimulus than non-EMEs during the Great Recession. For countries that were in the high or low growth categories during the pre-recession period also, fiscal expenditures of the consolidated government grew at a relatively slower pace during the pre-recession period but relatively faster during the recession period.

Not all of the differences in average growth are significantly difference from zero, due in part to the large differences between countries within groups, and over time. Table 6 presents the t-tests for the difference in average growth rates during different periods, between groups of 
countries. ${ }^{3}$ During the pre-recession period, federal unions saw significantly slower growth and high growth countries saw significantly faster growth in $G$ than their counterparts. In the recession period 2007Q4-2010Q1 also, countries that had seen higher growth in the prerecession period also saw significantly larger net fiscal stimulus, as did emerging market economies. ${ }^{4}$ Non-EMU federal unions also saw significantly faster growth of $G$ during the full recession period, 2007Q4-2010Q1 and during 2009Q1-2010Q1, than federal unions that are also part of EMU.

To summarize, a federalist structure by itself was not an impediment to a large fiscal stimulus during the Great Recession - to the contrary, federal unions were fiscally more conservative in the pre-recession period but delivered a significantly larger stimulus during the Great Recession period, than other countries. Being part of EMU, however changed things. EMU countries- whether federal unions or otherwise - were fiscally profligate during the pre-Great Recession period and fiscally more conservative during the Great Recession period. The Emerging economies were relatively fiscally responsible during the pre-recession period, and delivered larger stimuli during the Great Recession period, perhaps explaining their faster recovery. This suggests a countercyclical fiscal policy in emerging economies on the whole. In the next section, we measure the degree of countercyclicality for each country.

\section{On the countercyclicality of fiscal policy in different countries}

Emerging markets had strongly countercyclical policy during the period immediately preceding the Great Recession and the Great Recession. Many non-emerging OECD countries had procyclical fiscal policy stance in the same periods, contrary to historical experience.

A large body of empirical literature suggests that historically, fiscal policy has been countercyclical in the developed countries, and procyclical in emerging and developing economies (Kaminsky et.al., 2004 and references therein). To test whether and to what extent fiscal policy was countercyclical between the expansionary phase immediately preceding the Great Recession and the Great Recession period, we compute the amplitude of fiscal policy for each country, as in Kamisky et. al. (2004). This measure is the difference between the

\footnotetext{
${ }^{3}$ The t-tests are conducted on annual data, to smooth over large variations in quarter-on-quarter growth rates within the year.

${ }^{4}$ The two groups overlap to a large extent.
} 
(compound annual) growth rate of $G$ during the 'good time', 2004Q1-2007Q1 and its growth rate during the 'bad time'. We consider two periods to measure the growth rate during the 'bad time': the full recession period, 2007Q4-2010Q1 and only the later period, 2009Q1-2010Q1, to allow for lags in fiscal policy. A negative number indicates a countercyclical policy, as the $G$ grew faster in bad times than in good times, whereas a positive number indicates a procyclical policy. ${ }^{5}$

The amplitudes for different countries are plotted in Figures 2 and 3. For the period 2007Q4-2010Q1, Figure 2 shows that over half the countries in sample had a countercyclical policy, with the strongest countercyclicality being in Mexico, Australia, Korea, Finland, Portugal and Germany. The most procyclical policy was in Greece, Ireland, Hungary, Iceland and Turkey.

The USA also had a mildly countercyclical policy over these periods. However, this effect was entirely due to the expenditures during 2007Q4-2008Q4, which may have been determined before the crisis started. When only the second half of the recession period is considered - 2009Q1-2010Q1, Figure 3 shows that USA was among the 13 countries that had a procyclical policy stance, as the $G$ of the consolidated government grew faster during 2004Q12007Q1 than it did during 2009Q1-2010Q1. Of the 7 countries in the sample that are also federal unions, three - USA, Belgium and Austria - had procyclical fiscal policy over the cycle, whereas four - Mexico, Australia, Canada and Germany - saw countercyclical fiscal policy.

Going beyond the most recent business cycle, we compare the cyclicality of fiscal policy in the past recession periods with the Great Recession. To do so, in Tables 4 and 5, we compute correlations between GDP growth and $G$ growth during the pre- and post-2007 periods, for different groups of countries using two different definitions of recession periods.

In table 4, we define recession periods as periods with at least two consecutive quarters of negative GDP growth for all countries except the USA. For the USA, NBER recession dates are used. For these recession periods, we compute the correlation between quarterly percentage change in GDP and the one year forward expansion in $G$, using two measures of such change. The first block in table 4 uses the year-on-year (YoY) change in (or the CAGR of) $G$ between the fourth quarter from the recession quarter and the recession quarter. The second block averages the QoQ change in $G$ over the four quarters after the recession quarter. For federal unions, the

\footnotetext{
${ }^{5}$ In Section III, we looked at growth rates of G during the Great Recession quarters only. In this section, we compare this growth with growth during the pre-Great Recession period, with other recession periods only and with other expansion and contraction periods.
} 
correlation between recession quarter declines in GDP and average YoY forward change in $G$ was negative and of comparable value in the pre-2007 and the Great Recession periods. For emerging markets, the correlation in the pre-2007 period is positive but in the Great Recession period is negative. However, these correlations are not significantly different from zero using any measure, indicating large differences between countries. The results are slightly different when average QoQ growth rates are used (with negative correlations in both periods), but as discussed earlier, the CAGR gives more accurate information about the change in $G$ over the entire period in question. For non-emerging OECD countries, the pre-2007 correlation coefficient was negative and significant, indicating a countercyclical fiscal policy, but positive and not significantly different from zero during the Great Recession period.

In Table 5, we present the correlations of the cyclical components of GDP and consolidated government $G$, after extracting the trend using Hodrick-Prescott (HP) filter. Here, the results are a bit different. For federal unions, the correlations in both periods (i.e., pre- and post- 2007) are positive, whereas for non-emerging OECD, they are negative and significant in both periods. For emerging markets, the fiscal policy is strongly countercyclical in the post-2007 period. There are two potential sources of the differences in results between the two tables: one, that the correlations using the HP filtered series uses information on good times as well as bad times, and two, that the correlations using cyclical components do not allow for lags in implementation of policy.

\section{Net fiscal stimulus and the flow costs of public debt}

Greater net fiscal stimulus was associated with lower flow costs of general government debt in the same or subsequent period.

We now turn to the question of whether countries that enacted larger fiscal stimuli had to face higher borrowing costs, i.e., we ask whether there was a positive association between the size of the net fiscal stimuli and the flow costs of public debt. The flow cost of public debt is the primary surplus the government needs to generate every year in order to keep the debt-GDP ratio constant. It is defined as the difference between the real rate of interest on general government bonds $(r)$ and the real GDP growth rate $(g)$, multiplied by the debt GDP ratio for general 
government debt $(d) .{ }^{6}$ Table 7 presents the correlations between net fiscal stimulus and the same period, and next period flow cost of public debt. These correlations are computed for the net fiscal stimuli during each of three periods, 2007Q4-2008Q4, 2009Q1-2010Q1 and 2007Q42010Q1. The top panel of the table presents the same period correlations between net fiscal stimulus and the same period flow cost of public debt. These are negative and significant for all periods under consideration, indicating that higher fiscal stimuli were associated with lower, not higher, flow costs of public debt in the same period.

However, correlation is not causation. The negative correlation is consistent with higher stimuli leading to lower flow costs of public debt, or with lower flow costs allowing higher stimuli to be enacted. In order to shed some light on the question of whether fiscal stimuli led to lower borrowing costs, in the lower panel, we compute the correlations between the net fiscal stimuli and the next period costs of public debt. These correlations are also all negative and two out of the three are also significantly different from zero.

Figure 5 clarifies the negative association. In this figure, we plot the compound annual growth of $G$ during 2007Q4-2010Q1 and the average of the flow costs over the same period. The countries with very large contractions of $G$ during this period had very large flow costs of public debt, whereas countries with very large expansions of $G$ during this period (Chile, Mexico, Australia, Korea, Poland) had very low, close to zero or negative flow costs. In Figure 6, we look at what is driving the flow costs by plotting its components over the period 2007Q4-2010Q1. The countries with the highest average flow costs had a combination of high interest rates and low real GDP growth rates, whereas for countries with the highest net fiscal stimuli, the real interest rate was similar to that in medium flow costs countries but the real GDP growth rate was considerably higher.

Figure 7, which is from Aizenman and Pasricha (2010) places the current flow cost in the context of the future projected costs, based on projected debt for 2015 and historical realizations of $(r-g)$ for each country. It shows that for most countries with low delivered stimulus, particularly the USA, the future expected flow costs of the public debt are also low, indicating

\footnotetext{
${ }^{6}$ As in Aizenman and Pasricha (2010), the interest rate used is the interest rate on local currency government bonds of the maturity closest to the effective maturity of government debt in each country. The nominal interest rates were converted to real rates by subtracting the rate of change of GDP deflator. Both the $r$ and $g$ series are available at a quarterly frequency by the debt GDP ratio is available at annual frequency. For data sources of each of the three series, $r, g$, and $d$, see the appendix.
} 
that the current or expected flow costs need not have constrained the size of the net fiscal stimulus.

\section{Central and state level spending in the delivery of net fiscal stimulus}

We turn now to the question of who delivered the stimulus - whether it was delivered by central or the regional governments. The data on central and state level pure fiscal expenditures was available for six countries - Norway, USA, United Kingdom, Sweden, Iceland and Australia, of which USA and Australia are federal unions. In Table 8, we present the compound annual growth rates of real GDP and of $C_{g}+I_{g}$ for each level of government for the three periods, 2007Q4-2008Q4, 2009Q1-2010Q1 and 2007Q4-2010Q1. Figures 8 and 9 plot the $C_{g}+$ $I_{g}$ growth over the period 2007Q4-2010Q4 and over 2009Q1-2010Q1 for all three levels of government. USA and Iceland were the only two countries of the six in which the state and local level spending fell over any of the three periods, and in both these countries, state and local level spending contracted in each of the three periods. In USA, an expansion in federal spending prevented a contraction in consolidated government spending in each of the three periods, as state and local level spending was falling. Australia saw the largest net fiscal stimulus of these countries. In Australia, central as well as state and local level spending increased by over 9 percent during 2009Q1-2010Q1. The trends in government spending over the full recession period for each country can be seen in Figure 10.

To gauge the degree of countercyclicality of fiscal policy for each of the countries, in Figures 11 and 12, we plot the ratio of the growth rates of $C_{g}+I_{g}$ and real GDP, for each level of government, for the period 2007Q4-2010Q1 and 2009Q1-2010Q1. Norway, Sweden and UK had countercyclical fiscal policy at each level of government during2007Q4-2010Q1, whereas Australia had a procyclical fiscal policy, since its real GDP expanded over this period. In the USA, state and local level spending contracted, and the net fiscal stimulus was entirely the result of an expansion of federal spending. During 2009Q1-2010Q1, four countries, Australia, Sweden, Iceland and USA appear to have procyclical fiscal policy at the consolidated level. However, each had quite different experiences. In this period, GDP in the USA expanded and state and

local spending continued to contract. Australia and Sweden, real GDP also expanded along with 
$C_{g}+I_{g}$ at each level of government. However, in Iceland, real GDP as well as $C_{g}+I_{g}$ at each level of government fell.

This leads to the question of whether the central and region spending patterns during the Great Recession were comparable to those in the previous recessions. In Table 9, we present panel regressions, using fixed effects estimators, for explaining changes in $G, G^{c}$ and $G^{s}$ during recession periods before 2007 and during the Great Recession. The left-hand side variable is the quarter-on-quarter change in $C_{g}+I_{g}$ for the given level of government, in the fourth quarter from each recession quarter. The explanatory variables are the quarter-on-quarter change in real GDP during the current recession quarter, and its two lags and leads. For the state and local level spending, the partial correlations with real GDP are either not significantly different from zero, or positive and significant at 10 percent level of significance, indicating a procyclical fiscal policy at the state and local level on average. The central level changes in spending are not well explained in the pre-2007 period, and during the Great Recession, are countercyclical to twoquarter lagged GDP but procyclical to 3-quarters lagged GDP. The consolidated government spending was negatively related to two-quarter or four-quarter lagged GDP during the Great Recession, but not in the pre-2007 period, during which the only significant association is positive.

\section{Conclusions}

The main results of this paper are:

1. The countries with the largest net fiscal stimuli during the Great Recession were Portugal, Australia, Mexico, Korea, Chile and Canada. Six out of 28 OECD countries had negative net fiscal stimuli. These were Greece, Iceland, Ireland, Poland, Austria and Italy. The USA is ranked $9^{\text {th }}$ from the bottom in the size of its net fiscal stimulus.

2. Federal unions, emerging markets and countries with very high GDP growth preRecession enacted larger stimuli on average than others.

3. Emerging markets enacted strongly countercyclical fiscal policy during the business cycle consisting of the pre-Great Recession and the Great Recession periods, whereas several developed OECD countries had a pro-cyclical fiscal policy stance. 
4. Larger net fiscal stimuli were associated with lower flow costs of public debt in the same and the subsequent periods.

5. There was no significant net fiscal stimulus without help from the regional governments.

The above results describe the patterns in the distribution of net fiscal stimuli in OECD countries during the Great Recession. However, why these patterns exist is an open question, in need for future research. We close the paper with an outline of some of the underlying issues. The overall timid fiscal stimuli of the developed members of the OECD (including the US) relative to emerging markets may be either the outcome of a well functioning automatic stabilizers in the higher GDP per capita countries, or possible overreaction of developed OECD countries that switched from fiscal laxity during the great moderation to relative fiscal frugality during the Great Recession. While Greece and Ireland had very limited fiscal space during the Great Recession, this seems not to be the case with most other OECD countries. The evidence of the relatively low projected flow cost of servicing the future public debt for about half of the OECD countries raises related questions. The fiscal fatigue of various OECD counties in 2010 may reflect cautious prudent approach, possibly due to concerns about the greater exposure to downside risks associated with aging population and an over-extended welfare state. Alternatively, it may reflect overshooting of policymakers' reactions, where fiscal issues that were swept aside during the great moderation period became the focal point of the present debate in the aftermath of the crisis.

Arguably, the resilience of the emerging markets relative to the developed OECD countries may reflect the lessons of the crisis of the 1990s, when emerging markets found that fiscal excesses and balance sheet exposure entail large downside risk. In contrast, most developed OECD countries viewed the 1990s and the first half of 2000s as affirmation of their sound fiscal positions. This reflected an optimistic assessment of future, propagated by the presumption that the great moderation would endure. In addition, the Euro project probably led to under-pricing of public debt in non-core countries, masking their growing fiscal vulnerabilities. The degree to which the Great Recession would lead to enduring fiscal consolidation in OECD countries without overshooting in the short-run remains an open question. 


\section{References}

Aizenman, Joshua and Gurnain K Pasricha (2010), "Fiscal fragility: what the past may say about the future", NBER Working Paper 16478.

Kaminsky, Graciela, Carmen Reinhart, and Carlos A. Végh (2004), "When it rains, it pours: Procyclical capital flows and macroeconomic policies," NBER Macroeconomics Annual.

Ilzetzki, Ethan, Enrique G. Mendoza and Carlos A. Végh (2010) "How Big (Small?) are Fiscal Multipliers?," manuscript, University of Maryland.

Treisman, Daniel (2000), “The causes of corruption: a cross-national study” Journal of Public Economics, 76, 399-457. 
Table 1: Countries for which quarterly data on $G$ is available

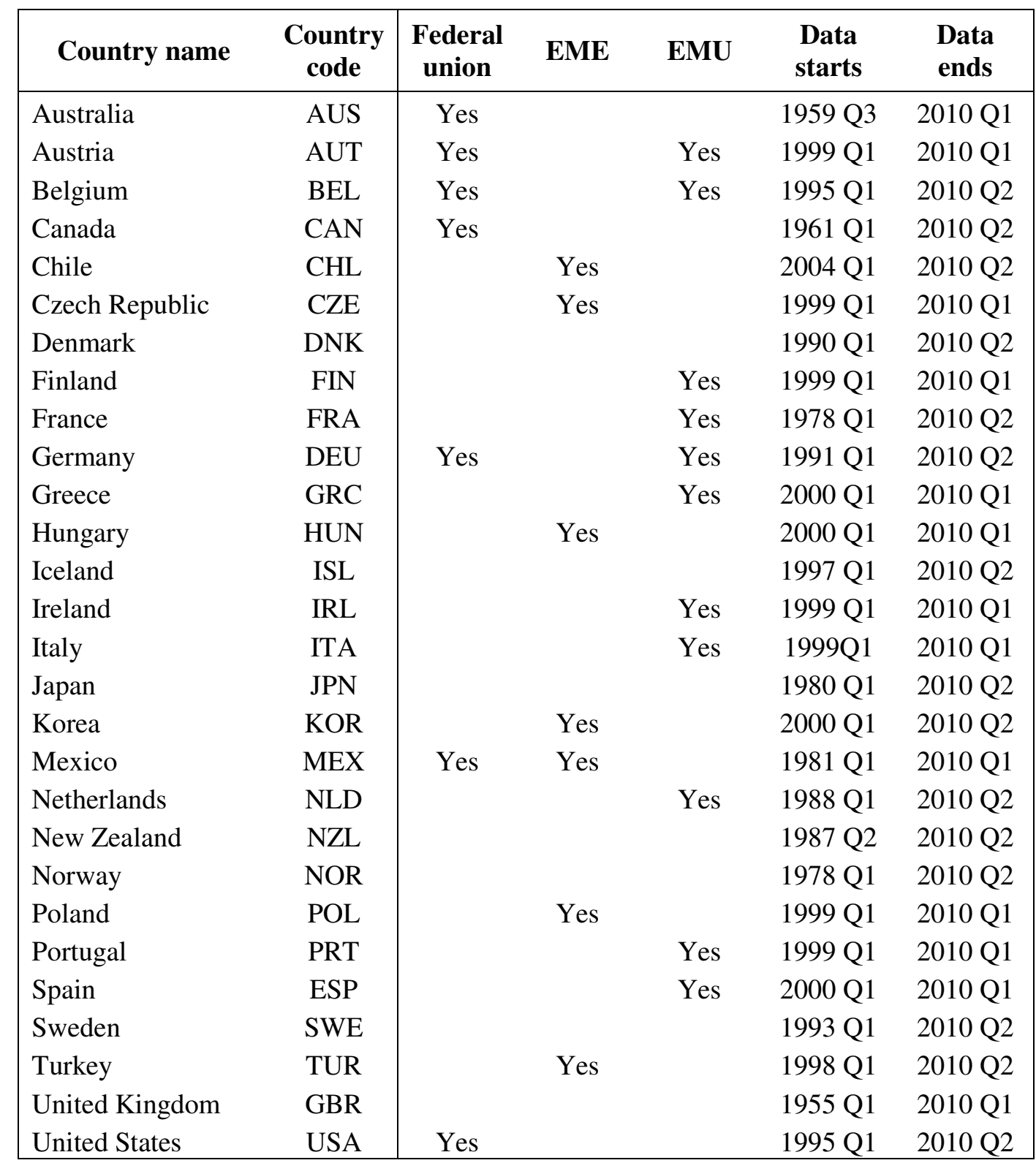

Note: EME stands for Emerging Market Economy, and EMU stands for European Monetary Union. 
Table 2: Size of the net fiscal stimulus by the consolidated government:

Confidence intervals using pre-crisis $G$ growth

\begin{tabular}{|c|c|c|c|c|c|c|c|}
\hline \multirow{3}{*}{$\begin{array}{l}\text { Country } \\
\text { AUS }\end{array}$} & \multicolumn{3}{|c|}{ Annualized QoQ growth rates of $G$} & \multicolumn{4}{|c|}{$\begin{array}{l}\text { Confidence intervals using pre-crisis } \\
\qquad \text { growth } \\
\text { (Pre-crisis period }=2004 Q 1 \text { to } 2007 \mathrm{Q} 1 \text { ) }\end{array}$} \\
\hline & \multirow{2}{*}{$\begin{array}{c}\text { 2007Q4- } \\
\text { 2008Q4 } \\
5.37\end{array}$} & \multirow{2}{*}{$\begin{array}{c}\text { 2009Q1- } \\
\text { 2010Q1 } \\
9.11\end{array}$} & \multirow{2}{*}{$\begin{array}{c}\text { 2007Q4- } \\
\text { 2010Q1 } \\
7.24\end{array}$} & \multicolumn{2}{|c|}{ Mean +/- SD } & \multicolumn{2}{|c|}{ Mean+-2*SD } \\
\hline & & & & -1.43 & 8.21 & -6.25 & 13.03 \\
\hline AUT & 2.36 & -1.23 & 0.57 & -0.98 & 4.98 & -3.96 & 7.95 \\
\hline BEL & 2.70 & 0.30 & 1.50 & -5.62 & 8.99 & -12.93 & 16.30 \\
\hline CAN & 3.70 & 5.79 & 4.74 & 1.41 & 3.94 & 0.15 & 5.20 \\
\hline CHL & 15.23 & 10.30 & 12.77 & -31.05 & 38.24 & -65.70 & 72.89 \\
\hline CZE & 7.64 & 3.60 & 5.62 & -10.05 & 12.75 & -21.45 & 24.15 \\
\hline DEU & 3.12 & 2.86 & 2.99 & -3.95 & 5.11 & -8.48 & 9.65 \\
\hline DNK & 1.48 & 4.10 & 2.79 & -1.44 & 6.32 & -5.32 & 10.20 \\
\hline ESP & 5.13 & 3.95 & 4.54 & -3.24 & 14.88 & -12.31 & 23.94 \\
\hline FIN & 5.02 & 4.57 & 4.80 & -3.84 & 8.30 & -9.91 & 14.37 \\
\hline FRA & 1.40 & 2.05 & 1.73 & 0.64 & 2.68 & -0.39 & 3.70 \\
\hline GBR & 3.30 & 3.47 & 3.38 & -35.25 & 42.92 & -74.33 & 82.00 \\
\hline GRC & 1.24 & -13.95 & -6.36 & -9.14 & 14.99 & -21.20 & 27.05 \\
\hline HUN & -8.75 & 3.24 & -2.76 & -55.48 & 74.17 & -120.31 & 139.00 \\
\hline IRL & 1.54 & -3.44 & -0.95 & -5.54 & 20.47 & -18.54 & 33.47 \\
\hline ISL & 3.67 & -7.91 & -2.12 & -2.67 & 10.94 & -9.47 & 17.75 \\
\hline ITA & 2.52 & -0.95 & 0.78 & -9.06 & 9.93 & -18.56 & 19.43 \\
\hline JPN & -0.30 & 2.54 & 1.12 & -5.89 & 4.30 & -10.98 & 9.39 \\
\hline KOR & 2.10 & 8.92 & 5.51 & -5.26 & 9.96 & -12.87 & 17.57 \\
\hline MEX & 9.27 & 11.72 & 10.49 & -28.17 & 29.04 & -56.78 & 57.65 \\
\hline NLD & 3.17 & 2.42 & 2.79 & -3.99 & 11.12 & -11.54 & 18.67 \\
\hline NOR & 5.32 & 2.54 & 3.93 & -7.87 & 11.87 & -17.74 & 21.74 \\
\hline NZL & 4.91 & 0.21 & 2.56 & -8.08 & 18.43 & -21.34 & 31.69 \\
\hline POL & 12.29 & -1.28 & 5.51 & -4.48 & 19.19 & -16.31 & 31.02 \\
\hline PRT & -6.77 & 13.35 & 3.29 & -13.51 & 13.74 & -27.14 & 27.37 \\
\hline SWE & 1.23 & 1.58 & 1.41 & -3.92 & 5.67 & -8.71 & 10.46 \\
\hline TUR & 3.12 & 1.73 & 2.43 & -8.75 & 22.52 & -24.39 & 38.15 \\
\hline USA & 2.67 & 0.31 & 1.49 & -1.00 & 2.64 & -2.82 & 4.46 \\
\hline
\end{tabular}

Note: SD stands for standard deviation of quarter-on-quarter (QoQ) $G=C_{g}+I_{g}$ growth during the pre-crisis period. Annualized QoQ growth rates that exceed the upper bound of the narrower confidence interval are given in blue, while those that are below the lower bound of the narrower confidence interval are given in red. 
Table 3: Size of the net fiscal stimulus by the consolidated government:

Confidence intervals using pre-crisis GDP growth

\begin{tabular}{|c|c|c|c|c|c|c|c|}
\hline \multirow{3}{*}{$\begin{array}{l}\text { Country } \\
\text { AUS }\end{array}$} & \multicolumn{3}{|c|}{$\begin{array}{c}\text { Annualized QoQ growth rates of } G \\
\text { Average over period }\end{array}$} & \multicolumn{4}{|c|}{$\begin{array}{c}\text { Confidence intervals using pre-crisis GDP } \\
\text { growth } \\
\text { (Pre-crisis period }=2004 \mathrm{Q} 1 \text { to 2007Q1) }\end{array}$} \\
\hline & $\begin{array}{l}\text { 2007Q4- } \\
\text { 2008Q4 } \\
\end{array}$ & $\begin{array}{l}\text { 2009Q1- } \\
\text { 2010Q1 }\end{array}$ & $\begin{array}{l}\text { 2007Q4- } \\
\text { 2010Q1 } \\
\end{array}$ & \multicolumn{2}{|c|}{ Mean +/- SD } & \multicolumn{2}{|c|}{ Mean+-2*SD } \\
\hline & 5.37 & 9.11 & 7.24 & 1.48 & 5.09 & -0.32 & 6.89 \\
\hline AUT & 2.36 & -1.23 & 0.57 & 2.05 & 4.92 & 0.62 & 6.35 \\
\hline BEL & 2.70 & 0.30 & 1.50 & 1.42 & 4.32 & -0.04 & 5.78 \\
\hline CAN & 3.70 & 5.79 & 4.74 & 1.40 & 4.29 & -0.04 & 5.73 \\
\hline CHL & 15.23 & 10.30 & 12.77 & 2.26 & 9.25 & -1.24 & 12.74 \\
\hline CZE & 7.64 & 3.60 & 5.62 & 4.60 & 8.09 & 2.86 & 9.83 \\
\hline DEU & 3.12 & 2.86 & 2.99 & 0.09 & 4.05 & -1.89 & 6.04 \\
\hline DNK & 1.48 & 4.10 & 2.79 & -2.58 & 7.71 & -7.72 & 12.86 \\
\hline ESP & 5.13 & 3.95 & 4.54 & 3.17 & 4.26 & 2.62 & 4.81 \\
\hline FIN & 5.02 & 4.57 & 4.80 & 0.61 & 8.09 & -3.13 & 11.83 \\
\hline FRA & 1.40 & 2.05 & 1.73 & 1.14 & 3.35 & 0.03 & 4.45 \\
\hline GBR & 3.30 & 3.47 & 3.38 & 1.44 & 3.76 & 0.28 & 4.93 \\
\hline GRC & 1.24 & -13.95 & -6.36 & 0.63 & 7.39 & -2.74 & 10.76 \\
\hline HUN & -8.75 & 3.24 & -2.76 & 1.10 & 5.79 & -1.25 & 8.14 \\
\hline IRL & 1.54 & -3.44 & -0.95 & -1.34 & 12.10 & -8.05 & 18.81 \\
\hline ISL & 3.67 & -7.91 & -2.12 & -5.08 & 17.98 & -16.61 & 29.51 \\
\hline ITA & 2.52 & -0.95 & 0.78 & 0.36 & 2.85 & -0.89 & 4.09 \\
\hline JPN & -0.30 & 2.54 & 1.12 & -0.14 & 4.40 & -2.41 & 6.68 \\
\hline KOR & 2.10 & 8.92 & 5.51 & 2.58 & 5.88 & 0.93 & 7.53 \\
\hline MEX & 9.27 & 11.72 & 10.49 & -8.68 & 14.29 & -20.17 & 25.78 \\
\hline NLD & 3.17 & 2.42 & 2.79 & 1.10 & 4.90 & -0.81 & 6.81 \\
\hline NOR & 5.32 & 2.54 & 3.93 & -1.70 & 6.54 & -5.82 & 10.66 \\
\hline NZL & 4.91 & 0.21 & 2.56 & 0.17 & 5.99 & -2.74 & 8.90 \\
\hline POL & 12.29 & -1.28 & 5.51 & 2.04 & 8.58 & -1.23 & 11.85 \\
\hline PRT & -6.77 & 13.35 & 3.29 & -1.34 & 4.93 & -4.47 & 8.07 \\
\hline SWE & 1.23 & 1.58 & 1.41 & 0.57 & 7.93 & -3.11 & 11.61 \\
\hline TUR & 3.12 & 1.73 & 2.43 & 2.35 & 13.00 & -2.97 & 18.32 \\
\hline USA & 2.67 & 0.31 & 1.49 & 1.22 & 3.92 & -0.13 & 5.28 \\
\hline
\end{tabular}

Note: SD stands for standard deviation of quarter-on-quarter (QoQ) GDP growth during the pre-crisis period.

Annualized QoQ growth rates that exceed the upper bound of the narrower confidence interval are given in blue, while those that are below the lower bound of the narrower confidence interval are given in red. 
Table 4: Correlations between quarterly change in GDP during each recession quarter and one year forward change in $G$

\begin{tabular}{|c|c|c|c|c|c|c|}
\hline & \multicolumn{3}{|c|}{ Using YoY change in G } & \multicolumn{3}{|c|}{$\begin{array}{l}\text { Using average QoQ change } \\
\text { over the next year in } G\end{array}$} \\
\hline & $\mathbf{N}$ & Correlation & p-value & $\mathbf{N}$ & Correlation & p-value \\
\hline \multirow{3}{*}{$\begin{array}{l}\text { Federal Unions } \\
\text { Pre-2007 } \\
\text { Great Recession }\end{array}$} & & & & & & \\
\hline & 62 & -0.13 & 0.30 & 62 & -0.32 & 0.01 \\
\hline & 27 & -0.1 & 0.62 & 27 & -0.19 & 0.34 \\
\hline \multicolumn{7}{|l|}{ Emerging Markets } \\
\hline Pre-2007 & 19 & 0.04 & 0.87 & 19 & -0.12 & 0.63 \\
\hline & 28 & -0.14 & 0.47 & 28 & -0.18 & 0.35 \\
\hline \multicolumn{7}{|l|}{ Non-Emerging OECD } \\
\hline Pre-2007 & 128 & -0.05 & 0.61 & 128 & -0.05 & 0.55 \\
\hline Great Recession & 83 & 0.18 & 0.10 & 83 & 0.19 & 0.09 \\
\hline
\end{tabular}

Note: Recession Periods are those with at least two consecutive quarters of negative real GDP growth. All such recession quarters are included in correlation computation. One-year forward YoY change refers to change between the $4^{\text {th }}$ quarter from the recession quarter and the current recession quarter. Average QoQ change over the next year is the average of the quarter-on-quarter changes over the four quarters after the recession quarter. Great Recession Period refers to recession quarters during 2007, 2008, 2009 and 2010, up to 2010Q1. Values in red are correlations that are significant at 10 percent level.

Table 5: Correlations between HP-filtered components of real GDP and $G$

\begin{tabular}{|c|ccc|}
\hline & $\mathbf{N}$ & Correlation & p-value \\
\hline Federal Unions & & & \\
Pre-2007 & 1830 & 0.21 & 0.00 \\
Great Recession & 165 & 0.02 & 0.77 \\
Emerging Markets & & & \\
Pre-2007 & 736 & -0.03 & 0.49 \\
Great Recession & 129 & -0.41 & 0.00 \\
Non-Emerging OECD & & & \\
Pre-2007 & & & 0.00 \\
Great Recession & 2342 & -0.21 & 0.00 \\
\hline
\end{tabular}

Note: Values in red correspond to a p-value less than 0.10 . 
Table 6: T-tests for difference in average growth rate of $G$ between different country groups

\begin{tabular}{|c|c|c|c|c|c|c|}
\hline & \multicolumn{2}{|c|}{ Mean } & \multirow[b]{2}{*}{ t-statistic } & \multirow{2}{*}{$\begin{array}{c}\text { Two-tail test } \\
\text { p-value }\end{array}$} & \multicolumn{2}{|c|}{ One-tail test } \\
\hline & Group 1 & Group 0 & & & $\begin{array}{l}\text { Left p- } \\
\text { value }\end{array}$ & $\begin{array}{l}\text { Right } \mathrm{p} \text { - } \\
\text { value }\end{array}$ \\
\hline \multicolumn{7}{|c|}{ Period: 2004Q1-2007Q1 } \\
\hline Emerging Markets & 4.38 & 2.43 & -1.13 & 0.27 & 0.14 & 0.86 \\
\hline High Growth & 4.34 & 2.41 & -1.47 & 0.15 & 0.08 & 0.92 \\
\hline Low Growth vs. Moderate Growth & 2.26 & 2.49 & 0.24 & 0.81 & 0.59 & 0.41 \\
\hline EMU vs. Non-EMU & 2.37 & 3.26 & 0.93 & 0.36 & 0.82 & 0.18 \\
\hline EMU Federal Unions vs. Non-EMU & & & & & & \\
\hline Federal Unions & 0.84 & 2.29 & 1.04 & 0.31 & 0.84 & 0.16 \\
\hline \multicolumn{7}{|c|}{ Period: 2007Q4-2008Q4 } \\
\hline High Growth vs. Moderate Growth & 5.04 & 1.6 & -1.59 & 0.15 & 0.07 & 0.93 \\
\hline Low Growth vs. Moderate Growth & 0.59 & 1.6 & 0.58 & 0.58 & 0.71 & 0.29 \\
\hline EMU vs. Non-EMU & 1.46 & 2.69 & 0.81 & 0.43 & 0.79 & 0.21 \\
\hline EMU Federal Unions vs. Non-EMU & & & & & & \\
\hline Federal Unions & 3.16 & 3.16 & -0.01 & 1.00 & 0.50 & 0.50 \\
\hline \multicolumn{7}{|c|}{ Period: 2009Q1-2010Q1 } \\
\hline Federal Union & 4.18 & 3.41 & -0.36 & 0.73 & 0.36 & 0.64 \\
\hline Emerging Markets & 6.72 & 2.56 & -1.93 & 0.08 & 0.04 & 0.96 \\
\hline High Growth & 4.58 & 3.28 & -0.49 & 0.64 & 0.32 & 0.68 \\
\hline Low Growth & 4.59 & 3.27 & -0.58 & 0.58 & 0.29 & 0.71 \\
\hline High Growth vs. Moderate Growth & 4.58 & 2.62 & -0.71 & 0.49 & 0.25 & 0.75 \\
\hline High Growth & 4.81 & 2.27 & -1.54 & 0.14 & 0.07 & 0.93 \\
\hline Low Growth & 2.59 & 3.01 & 0.28 & 0.78 & 0.61 & 0.39 \\
\hline High Growth vs. Moderate Growth & 4.81 & 2.11 & -1.6 & 0.13 & 0.06 & 0.94 \\
\hline Low Growth vs. Moderate Growth & 2.59 & 2.11 & -0.31 & 0.76 & 0.38 & 0.62 \\
\hline EMU vs. Non-EMU & 1.87 & 3.57 & 1.36 & 0.18 & 0.91 & 0.09 \\
\hline $\begin{array}{l}\text { EMU Federal Unions vs. Non-EMU } \\
\text { Federal Unions }\end{array}$ & 1.92 & 4.98 & 2.02 & 0.07 & 0.97 & 0.03 \\
\hline
\end{tabular}

Note: The t-tests use the variation in annual average of quarter on quarter growth rates of consolidated government real consumption and investment expenditures for each country to test for difference in group means over each period, assuming unequal variances between groups. See footnotes to Figure 4 for definitions of various country groups. Group 1 is the first group mentioned in the row titles. For example, in the first row, group 1 refers to federal unions and group 0 is the alternative group, in this case, non-federal unions. 
Table 7: Correlations between net fiscal stimulus and average flow cost of public debt

\begin{tabular}{|c|c|c|c|}
\hline Growth of $\mathbf{G}$ during: & $\begin{array}{c}\text { Average of } \\
(\mathrm{r}-\mathrm{g}) * \mathrm{~d} \text {, during: }\end{array}$ & $\mathbf{N}$ & Correlation \\
\hline \multicolumn{4}{|c|}{ G growth and same period flow cost of public debt } \\
\hline 2007Q4 - 2008Q4 & 2007Q4 - 2008Q4 & 27 & -0.47 \\
\hline 2009Q1 - 2010Q1 & 2009Q1 - 2010Q1 & 27 & -0.39 \\
\hline 2007Q4 - 2010Q1 & 2007Q4 - 2010Q1 & 27 & -0.52 \\
\hline \multicolumn{4}{|c|}{ G growth and next period flow cost of public debt } \\
\hline 2007Q4 - 2008Q4 & 2009Q1 - 2010Q1 & 27 & -0.52 \\
\hline 2009Q1 - 2010Q1 & $2010 Q 2-2010 Q 3$ & 10 & -0.07 \\
\hline 2007Q4 - 2010Q1 & 2010Q2 - 2010Q3 & 10 & -0.56 \\
\hline
\end{tabular}

Note: CAGR is the compound annual growth rate over the period, $r$ is the real rate of interest on local currency government bonds of maturity closest to the average effective maturity of central government debt for each country, $g$ is the growth rate of real GDP and $d$ is the gross debt of the consolidated government as a percentage of GDP. For more details on these variables, see data appendix. Values in red correspond to a p-value less than 0.10 . 
Table 8: Growth of pure fiscal expenditures, by level of government, and real GDP growth Compound annual growth rates

\begin{tabular}{|l|ccc|c|}
\hline & \multicolumn{3}{|c|}{$C_{g}+I_{g}$} & \multirow{2}{*}{ Real GDP } \\
\cline { 2 - 3 } & $\begin{array}{c}\text { Consolidated } \\
\text { government }\end{array}$ & $\begin{array}{c}\text { Central } \\
\text { government }\end{array}$ & $\begin{array}{c}\text { State and } \\
\text { local }\end{array}$ & \\
\hline NO07Q4-2008Q4 & & & & \\
USA & 5.24 & 5.49 & 4.98 & -0.03 \\
GBR & 2.70 & 7.52 & -0.08 & -1.61 \\
SWE & 3.33 & 2.91 & 3.92 & -1.98 \\
ISL & 1.21 & -0.06 & 1.77 & -2.61 \\
AUS & 3.69 & 7.09 & -2.81 & -4.27 \\
\hline 2009Q1-2010Q1 & 5.41 & 3.60 & 6.49 & 1.31 \\
NOR & & & & \\
USA & 2.42 & -0.32 & 5.30 & -0.71 \\
GBR & 0.30 & 3.28 & -1.58 & 0.84 \\
SWE & 3.50 & 3.46 & 3.64 & -2.04 \\
ISL & 1.58 & 3.19 & 1.03 & 0.55 \\
AUS & -7.69 & -6.53 & -7.63 & -7.07 \\
\hline 2007Q4-2010Q1 & 9.36 & 9.28 & 9.41 & 3.03 \\
NOR & & & & \\
USA & 3.82 & 2.54 & 5.14 & -0.37 \\
GBR & 1.49 & 5.38 & -0.83 & -0.39 \\
SWE & 3.41 & 3.18 & 3.78 & -2.01 \\
ISL & 1.39 & 1.55 & 1.40 & -1.04 \\
AUS & -2.17 & 0.05 & -5.25 & -5.68 \\
\hline & 7.37 & 6.40 & 7.94 & 2.17 \\
\hline
\end{tabular}


Table 9: Regressions, for recession quarters defined as 2 or more consecutive quarters of negative growth

Dependent variable is 4-quarter ahead QoQ change in State and local, Consolidated or Central government $C_{g}+I_{g}$ Explanatory variables are current (recession) quarter QoQ change in GDP, and its 2 lags and leads.

\begin{tabular}{|c|c|c|c|c|c|c|}
\hline & \multicolumn{2}{|c|}{$\begin{array}{l}(1) \quad(2) \\
\text { State and local }\end{array}$} & \multicolumn{2}{|c|}{$\begin{array}{cc}(3) & (4) \\
\text { Consolidated government }\end{array}$} & \multicolumn{2}{|c|}{$\begin{array}{l}(5) \quad(6) \\
\text { Central government }\end{array}$} \\
\hline & Pre-2007 & $\begin{array}{c}2007 \text { and } \\
\text { later }\end{array}$ & Pre-2007 & $\begin{array}{l}2007 \text { and } \\
\text { later }\end{array}$ & Pre-2007 & $\begin{array}{l}2007 \text { and } \\
\text { later }\end{array}$ \\
\hline D.real GDP & $\begin{array}{l}-0.29 \\
(0.49)\end{array}$ & $\begin{array}{l}-0.66 \\
(0.56)\end{array}$ & $\begin{array}{l}-0.46 \\
(0.28)\end{array}$ & $\begin{array}{c}0.23 \\
(0.36)\end{array}$ & $\begin{array}{c}0.79 \\
(0.70)\end{array}$ & $\begin{array}{l}-0.96 \\
(1.52)\end{array}$ \\
\hline Next quarter D.real GDP & $\begin{array}{c}0.19 \\
(0.15)\end{array}$ & $\begin{array}{l}-0.18 \\
(0.51)\end{array}$ & $\begin{array}{l}0.40 * * * \\
(0.13)\end{array}$ & $\begin{array}{c}0.38 \\
(0.25)\end{array}$ & $\begin{array}{c}0.13 \\
(0.23)\end{array}$ & $\begin{array}{c}4.22 * * * \\
(1.06)\end{array}$ \\
\hline Two quarters ahead D.real GDP & $\begin{array}{l}0.24 * \\
(0.14)\end{array}$ & $\begin{array}{c}0.46 \\
(0.51)\end{array}$ & $\begin{array}{l}-0.09 \\
(0.12)\end{array}$ & $\begin{array}{c}-0.56^{* *} \\
(0.24)\end{array}$ & $\begin{array}{c}0.26 \\
(0.23)\end{array}$ & $\begin{array}{l}-2.41^{*} \\
(1.23)\end{array}$ \\
\hline Previous Quarter D.real GDP & $\begin{array}{c}0.28 \\
(0.25)\end{array}$ & $\begin{array}{l}0.64^{*} \\
(0.32)\end{array}$ & $\begin{array}{l}0.23 \\
(0.16)\end{array}$ & $\begin{array}{c}0.14 \\
(0.27)\end{array}$ & $\begin{array}{l}-0.38 \\
(0.34)\end{array}$ & $\begin{array}{c}0.50 \\
(0.96)\end{array}$ \\
\hline Two quarters ago D.real GDP & $\begin{array}{c}0.60 * * * \\
(0.21)\end{array}$ & $\begin{array}{l}-0.50 \\
(0.45)\end{array}$ & $\begin{array}{c}0.04 \\
(0.14)\end{array}$ & $\begin{array}{c}-1.10 * * * \\
(0.32)\end{array}$ & $\begin{array}{l}-0.10 \\
(0.30)\end{array}$ & $\begin{array}{l}-0.30 \\
(1.71)\end{array}$ \\
\hline $\begin{array}{l}\text { Observations } \\
\text { R-squared } \\
\text { Number of countries }\end{array}$ & $\begin{array}{c}64 \\
0.18 \\
6\end{array}$ & $\begin{array}{c}18 \\
0.76 \\
5\end{array}$ & $\begin{array}{c}146 \\
0.14 \\
20\end{array}$ & $\begin{array}{c}111 \\
0.19 \\
28\end{array}$ & $\begin{array}{c}71 \\
0.10 \\
8\end{array}$ & $\begin{array}{c}23 \\
0.70 \\
7\end{array}$ \\
\hline
\end{tabular}

Note: All regressions use fixed effects estimators. Standard errors are in parentheses. ${ }^{* * *} \mathrm{p}<0.01,{ }^{* *} \mathrm{p}<0.05,{ }^{*} \mathrm{p}<0.1$ 
Figure 1: Growth of consolidated government real $C_{g}+I_{g}$ Compound annual growth rates, by period

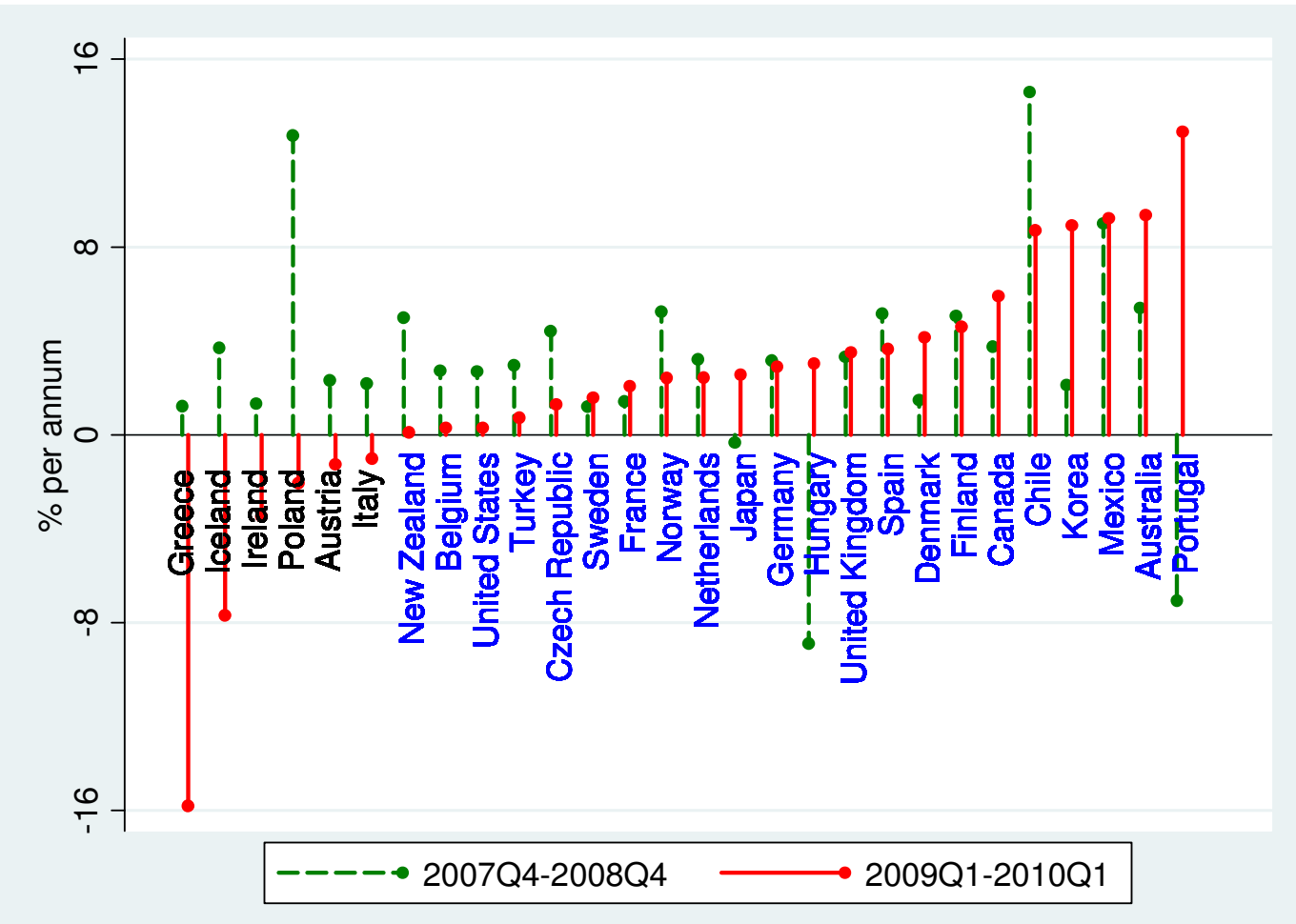


Figure 2: Many OECD countries had strongly pro-cyclical fiscal policy during the great recession and the expansionary period immediately preceding it.

Amplitude of fiscal policy between 2004Q1-2007Q1 and 2007Q4-2010Q1

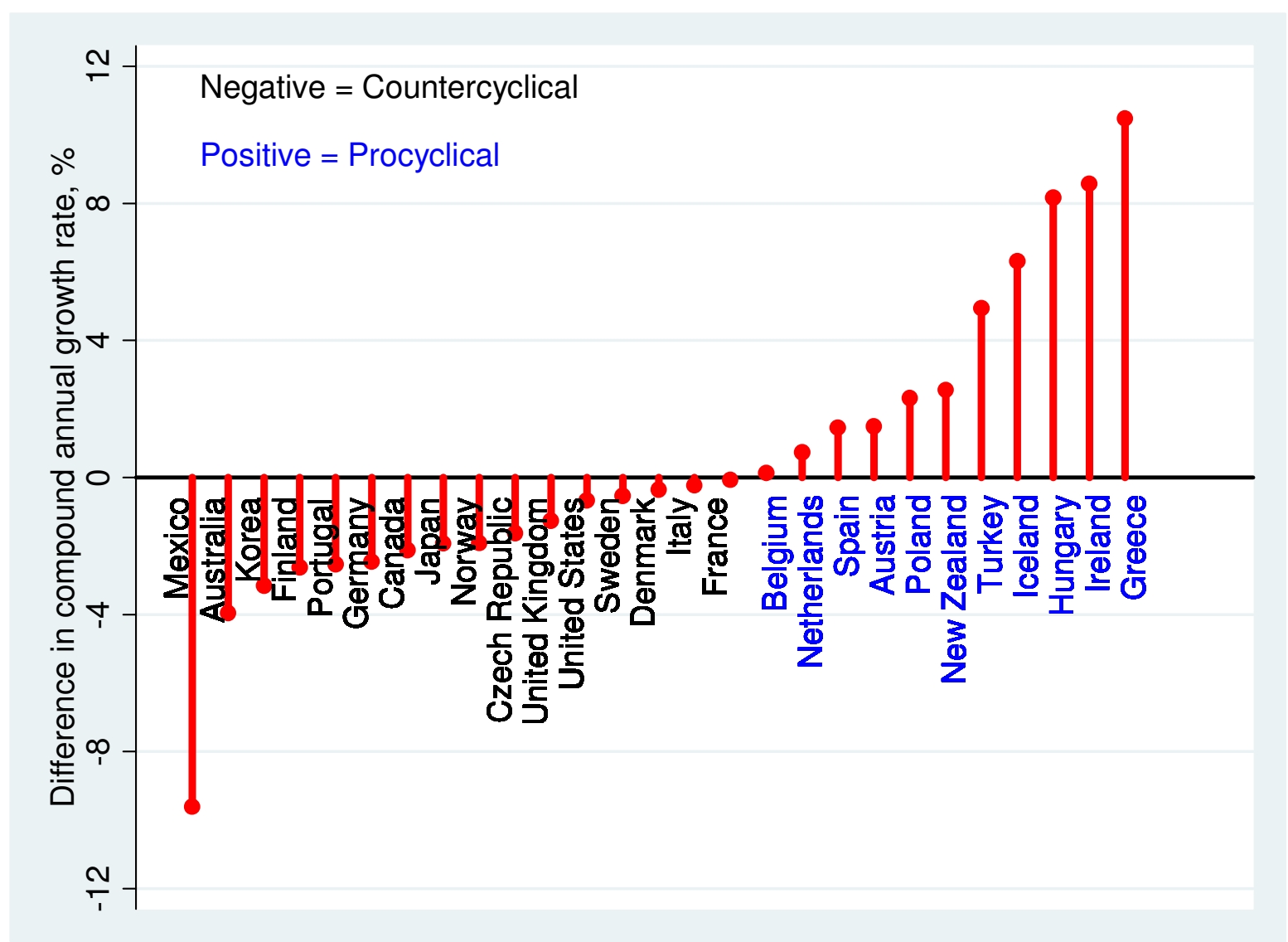

Note: Amplitude is defined as the difference between the Compound Annual Growth Rate (CAGR) of $G$ during the pre-recession period, 2004Q1-2007Q1, less the CAGR of $G$ during the full recession period, 2007Q4-2010Q1. A negative number implies counter-cyclical policy, whereas a positive number implies a pro-cyclical policy. 
Figure 3: The range of pro- or counter-cyclicality in fiscal policy across countries is larger when only the fiscal expansion since $2009 \mathrm{Q} 1$ is compared with pre-recession period.

Amplitude of fiscal policy between 2004Q1-2007Q1 and 2009Q1-2010Q1

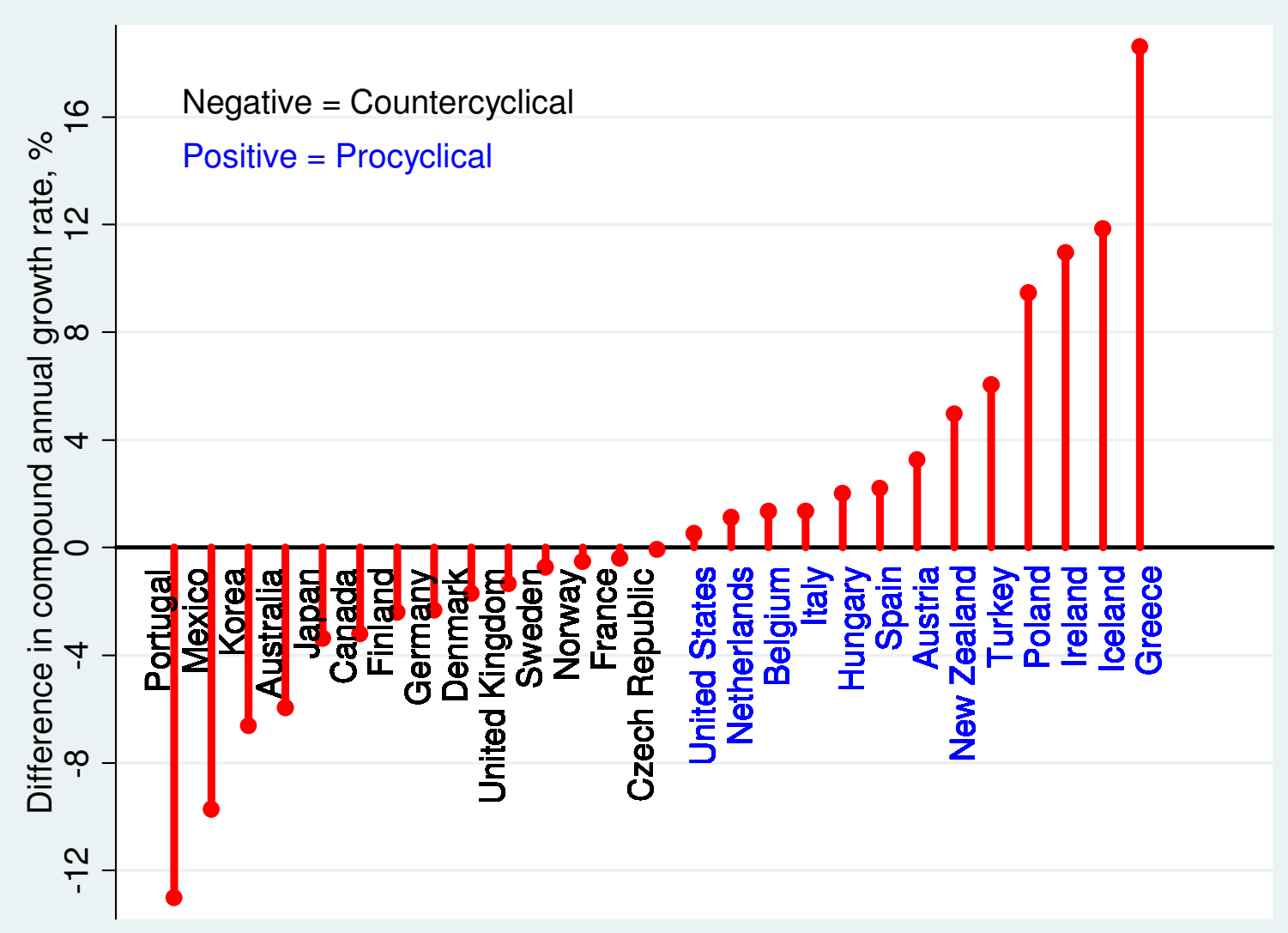

Note: Amplitude is defined as the difference between the Compound Annual Growth Rate (CAGR) of $G$ during the pre-recession period, 2004Q1-2007Q1, less the CAGR of $G$ during the period 2009Q1-2010Q1. A negative number implies countercyclical policy, whereas a positive number implies a pro-cyclical policy. 
Figure 4: Fiscal stimulus differed between country groups...emerging markets, federal unions and countries that saw extremes in GDP growth during pre-recession period managed higher stimulus than their counterparts.

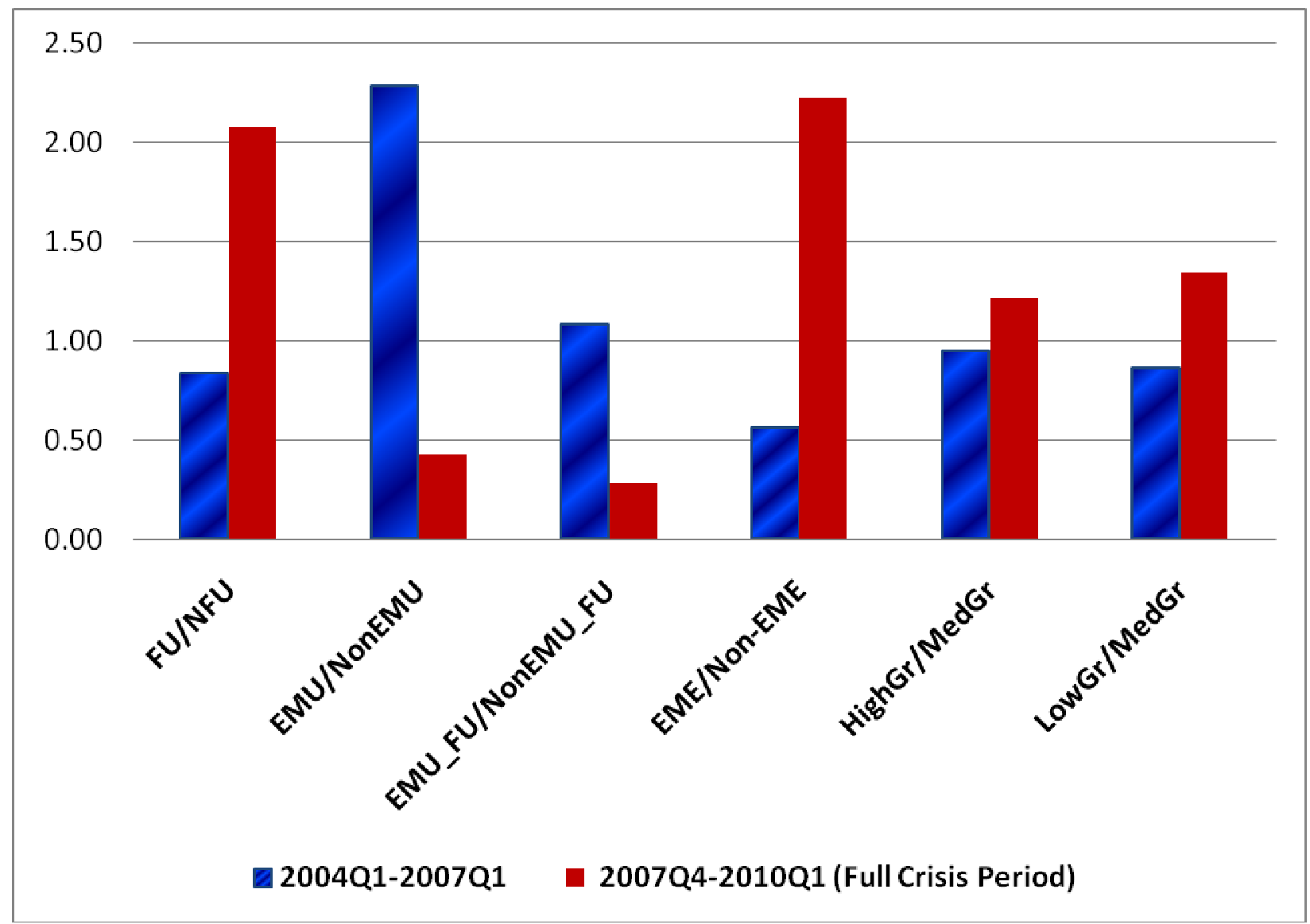

Note: The graph plots the relative average quarter-on-quarter (QoQ) growth of consolidated government $\mathrm{C}+\mathrm{I}$ over the relevant period and country group. For example, the blue shaded bar labelled FU/NFU plots the average QoQ growth of $G$ for countries that are federal unions divided by the average of such growth for non-federal unions in the sample. The abbreviations are: FU=Federal Unions, NFU=Non-Federal Unions, EMU = European Monetary Union countries, NonEMU = Non-EMU countries, EMU_FU = countries that are in EMU and are also federal unions (Austria, Belgium and Germany), NonEMU_FU = Non EMU countries that are federal unions (Australia, Canada, Mexico, Sweden, USA), EME = Emerging market economies, Non-EME = non-emerging market economies, HighGr = countries that had an average QoQ growth rate of GDP per capita during the period 2004Q1-2007Q1 in the top $25 \%$ of such growth rates for all OECD and federal union emerging economies in the sample. MedGr group includes countries that had GDP per capita growth defined as above, between $25^{\text {th }}$ and $75^{\text {th }}$ percentiles and LowGr countries are those whose GDP per capita growth was below the $25^{\text {th }}$ percentile of average GDP per capital growth during 2004Q1-2007Q1. For a list of countries in each group, see appendix table A1. 
Figure 5: Greater fiscal stimulus during the period 2007Q4-2010Q1 was associated with lower flow cost of consolidated government debt during the same period.

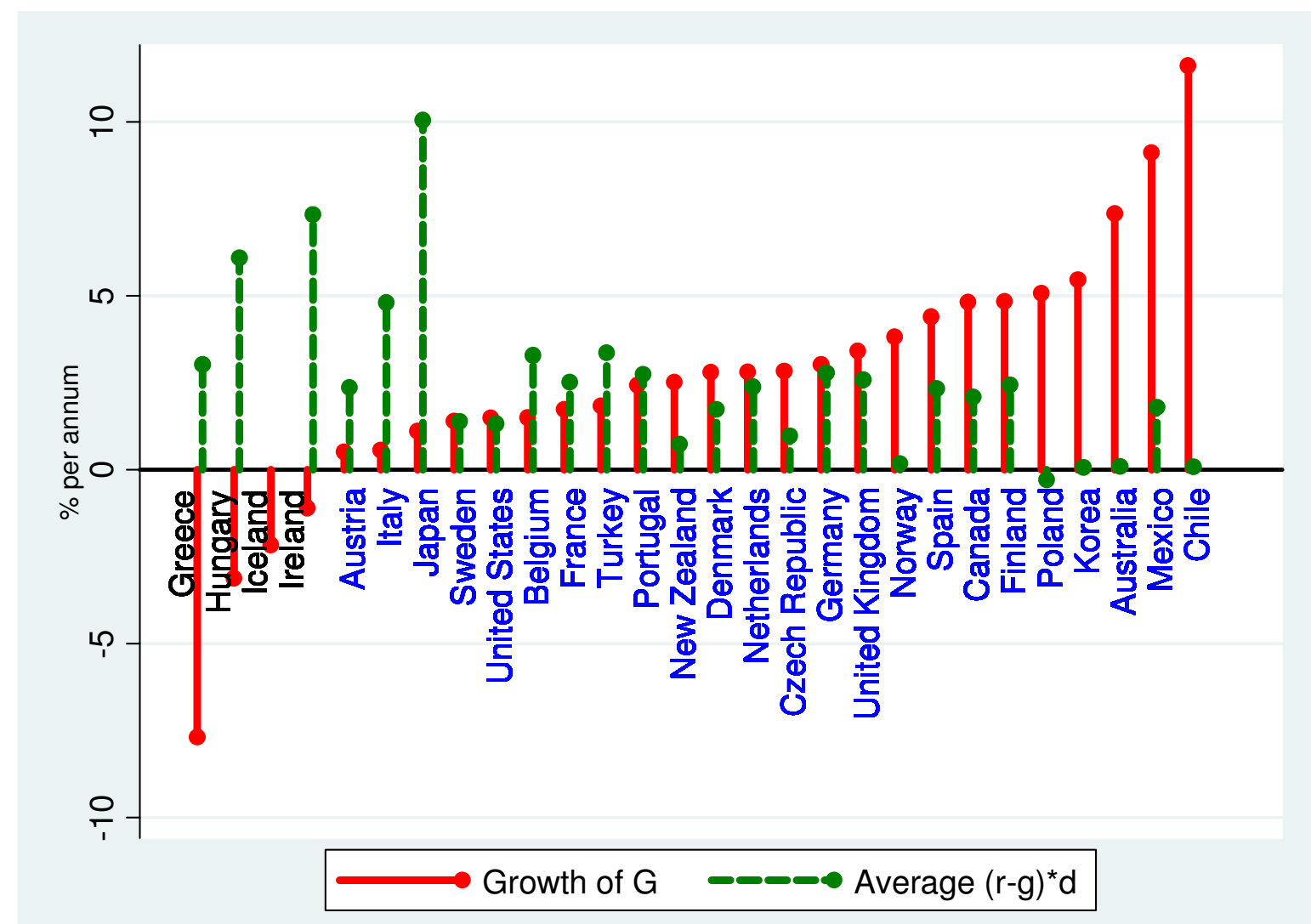

Note: Average $(r-g) * d$, 2007Q4-2010Q1 is the flow cost of consolidated government debt, measured by (real interest rate-real GDP growth rate)* Debt/GDP, averaged over the period 2007Q4-2010Q1. The Debt/GDP ratio uses the gross debt of the consolidated government and is available at an annual frequency. All other variables are measured at a quarterly frequency. 
Figure 6: Fiscal expansion and the components of flow costs of public debt. Countries are ranked in increasing order of CAGR of $G$ during 2007Q4-2010Q1.

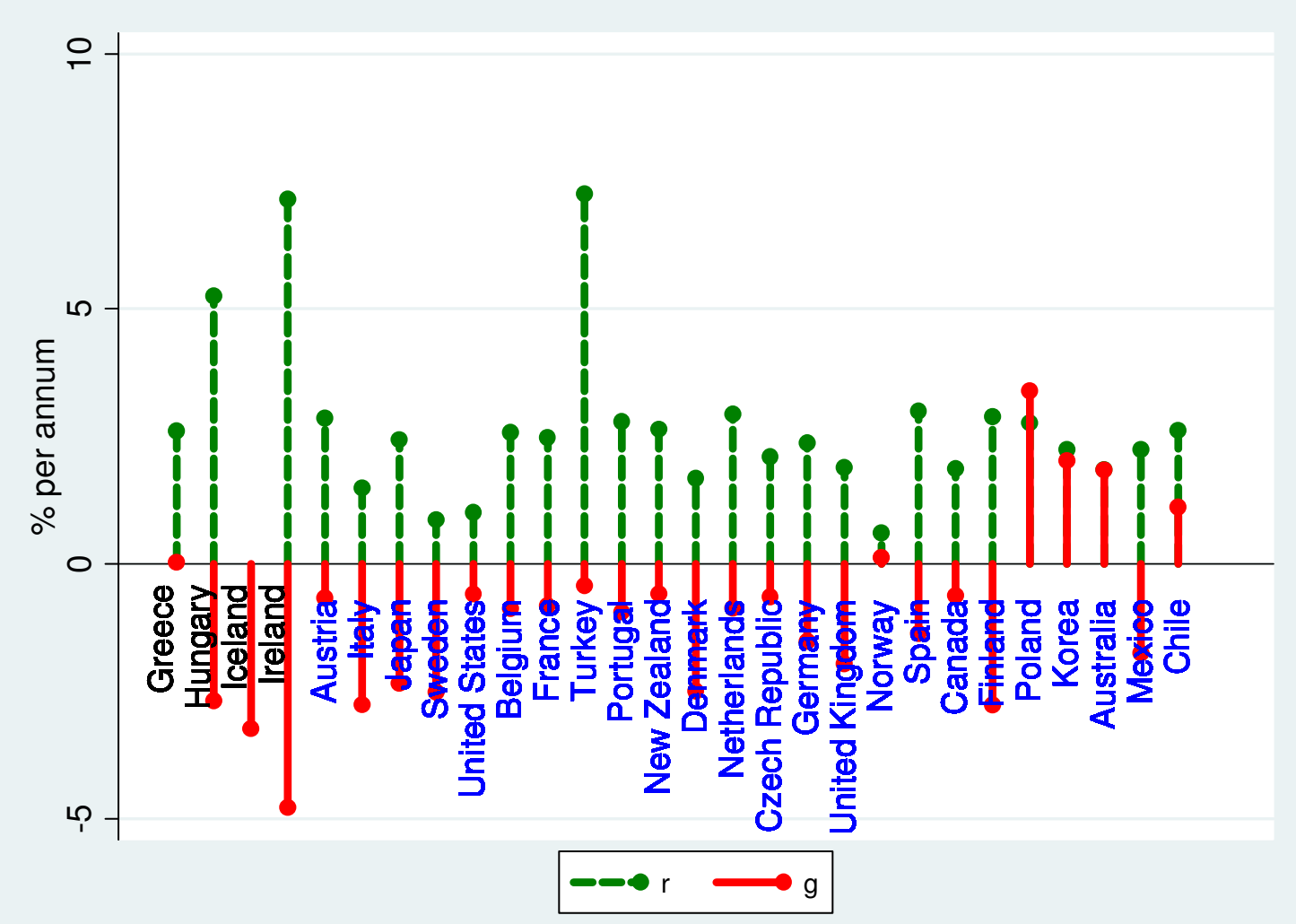

Note: CAGR is the Compound Annual Growth Rate over the relevant period, $r$ is the real interest rate on consolidated government debt and $\mathrm{g}$ is the real GDP growth rate. 
Figure 7: Consolidated government gross debt burden of selected OECD economies, historical best case, worst case and average scenarios (using projected $2015 \mathrm{debt/GDP)}$

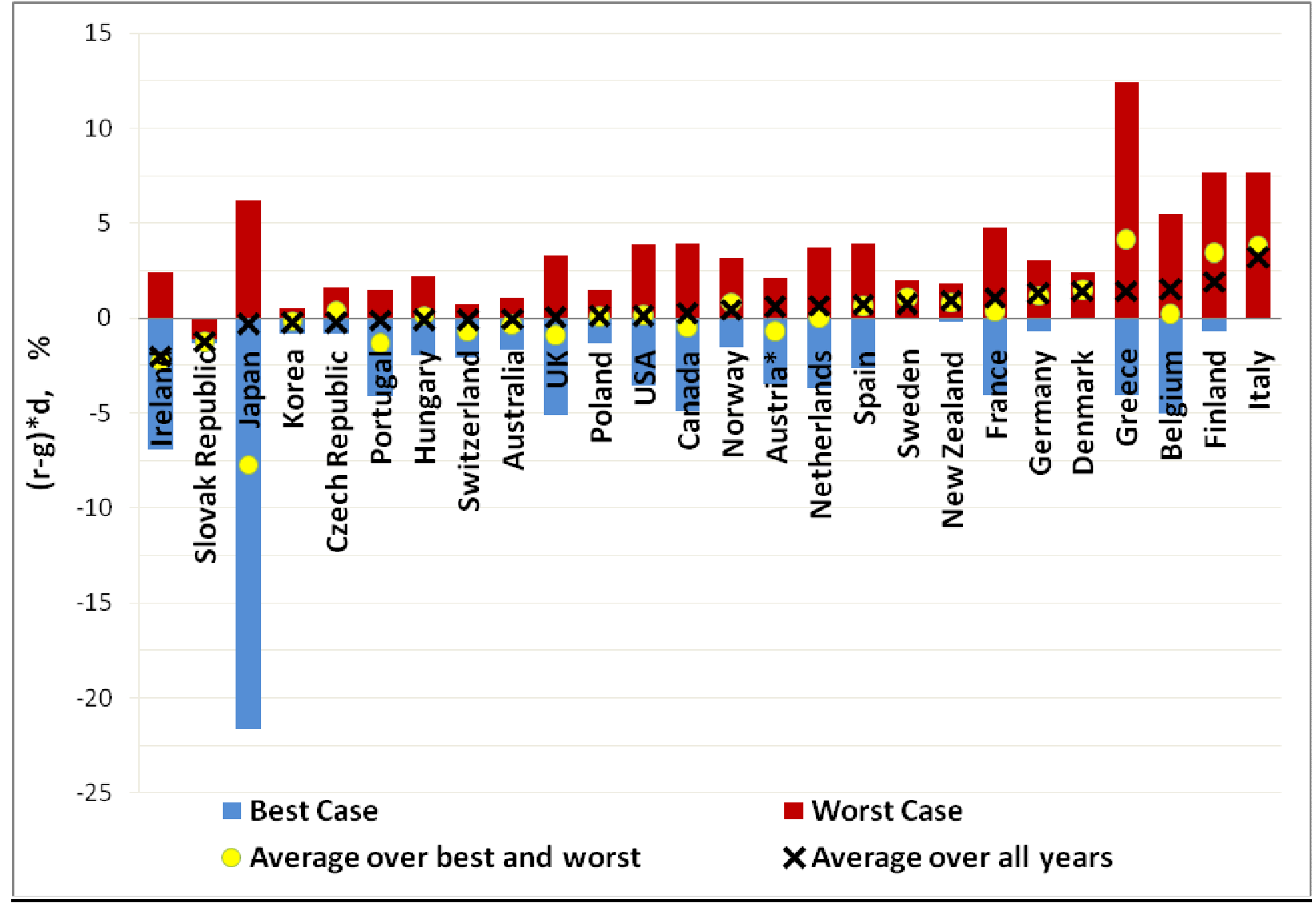

Note: The Figure is from Aizenman and Pasricha (2010). Countries are sorted by the lowest to highest average over all years. The gross debt burden representing the lowest (best scenario) and the highest (worst scenario) flow costs is calculated by taking the lowest and the highest historical values, respectively, of the $r$-g, and multiplying it with the projected 2015 gross government debt to GDP ratio. Real rates for Austria are based on the average return on bonds with maturities greater than one year for 1970-1982, and with a 9-10 year maturity for 1983-2010. Real rates for all other countries are the real rates on the maturity closes to the most recent average maturity of consolidated government debt in Table 2 of Aizenman and Pasricha (2010). The growth rate of GDP deflator was used to convert nominal interest rate to real rate. 
Figure 8: Except in the USA, net fiscal stimulus during the great recession involved an expansion of state and local level spending.

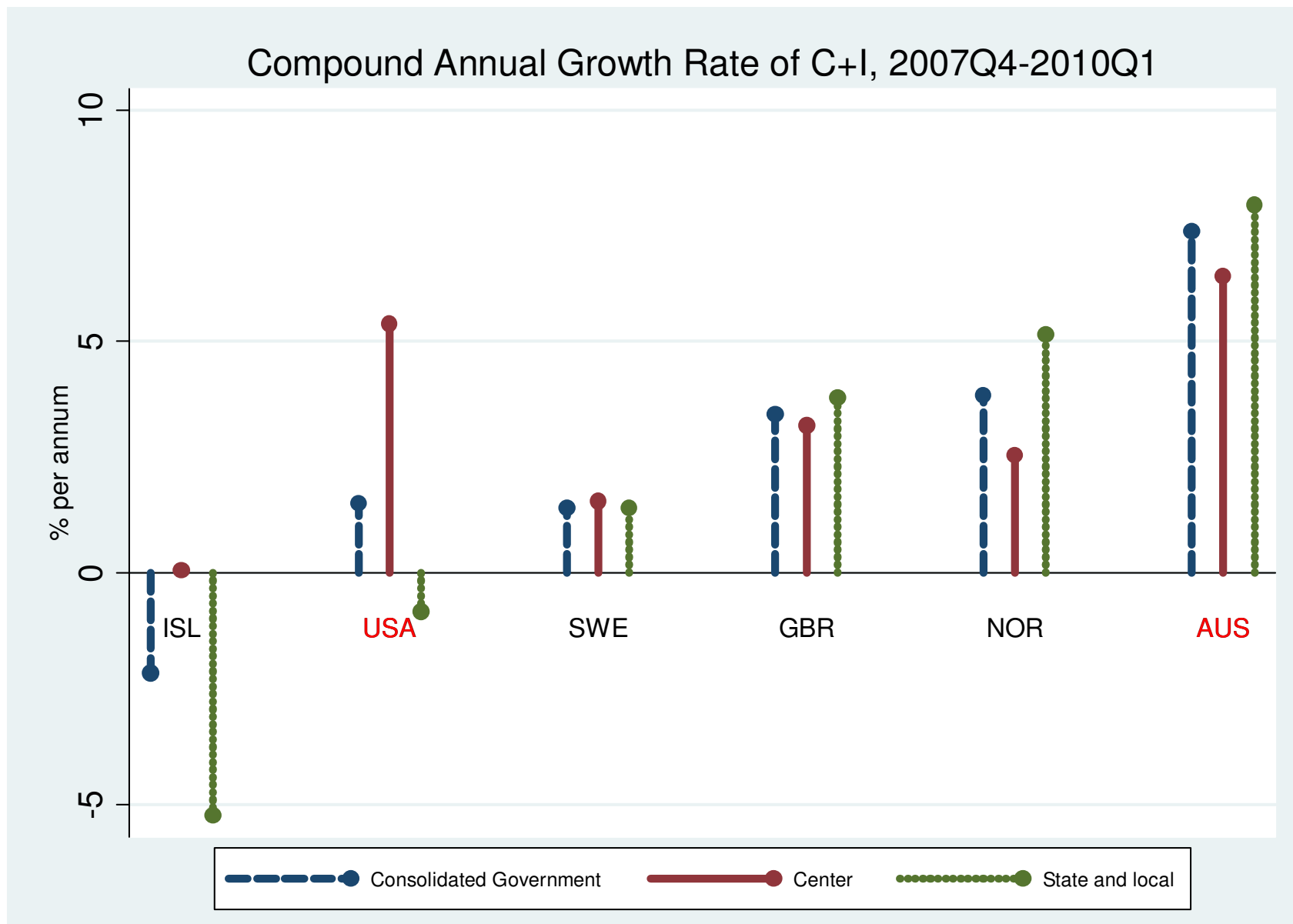

Note: Countries labelled in red are federal unions. For a list of country names associated with country codes, see Table 1. 
Figure 9: Contraction of state and local spending in the USA negated the expansion by the federal government, leading to negligible net fiscal stimulus by the consolidated government during 2009Q1-2010Q1.

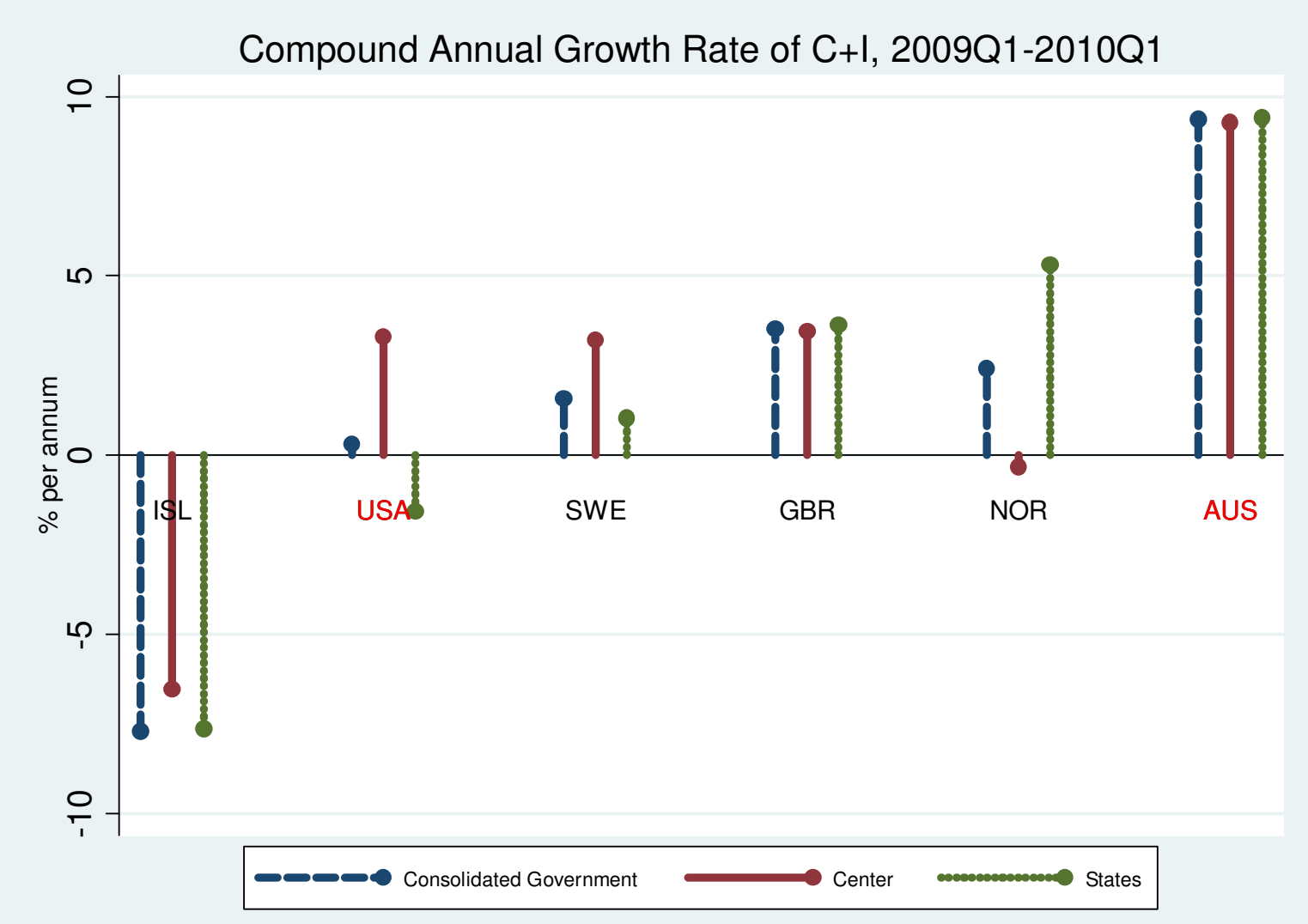

Note: Countries labelled in red are federal unions. For a list of country names associated with country codes, see Table 1. 
Figure 10: Pure fiscal expenditures, $\mathrm{C}+\mathrm{I}$, at each level of government

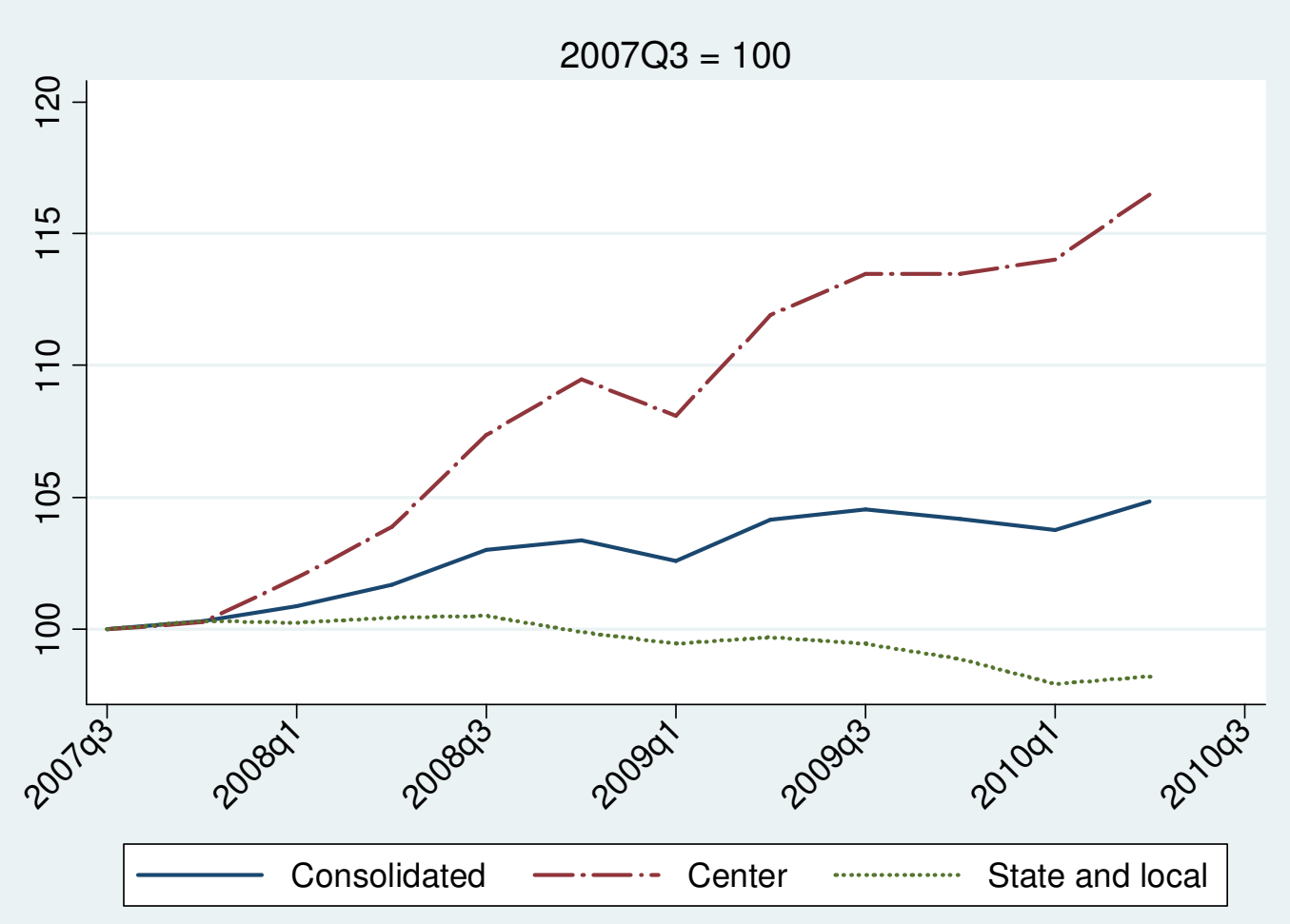

(a) United States

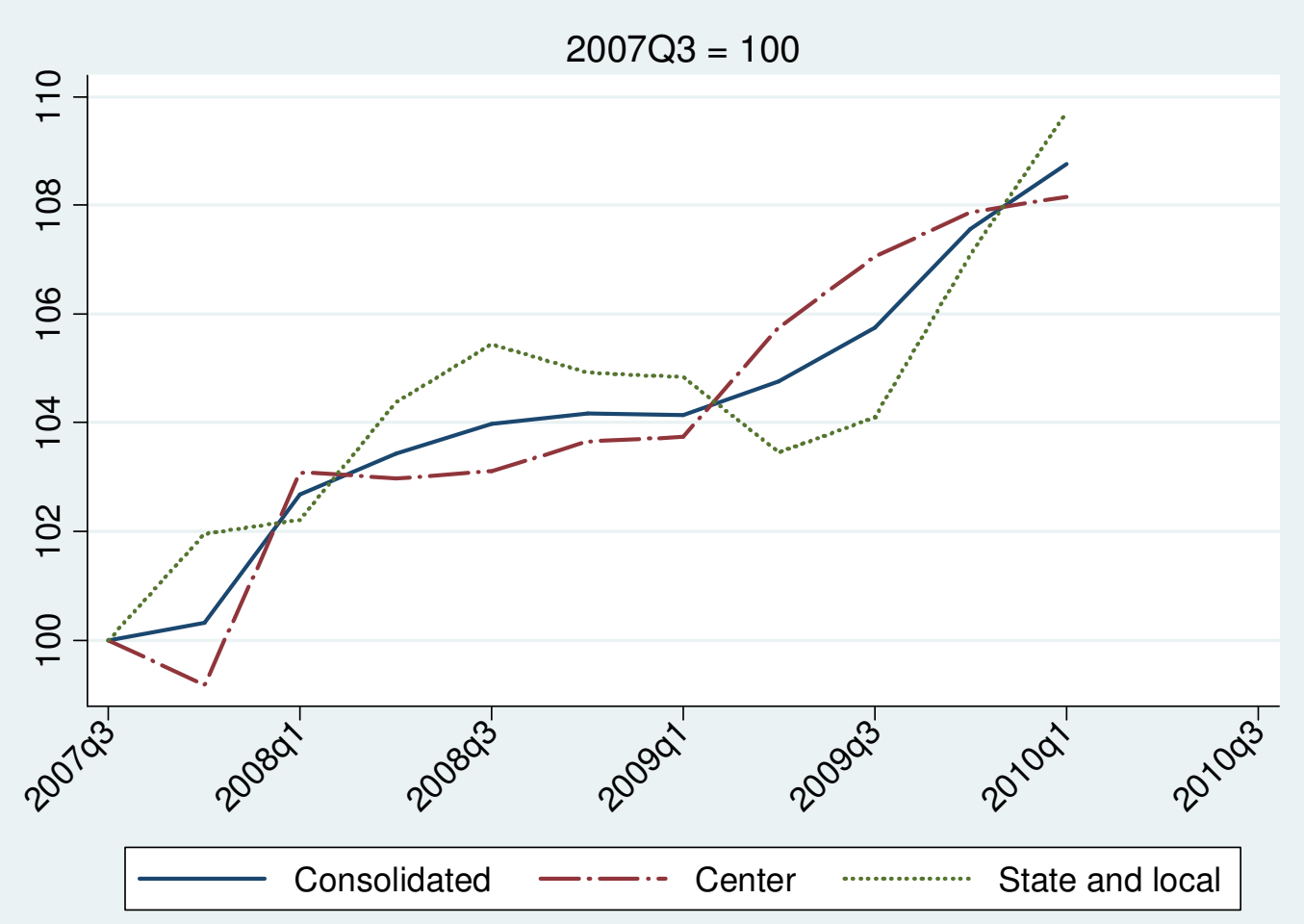


(b) United Kingdom

Figure 10 (contd.): Pure fiscal expenditures, $C+I$, at each level of government

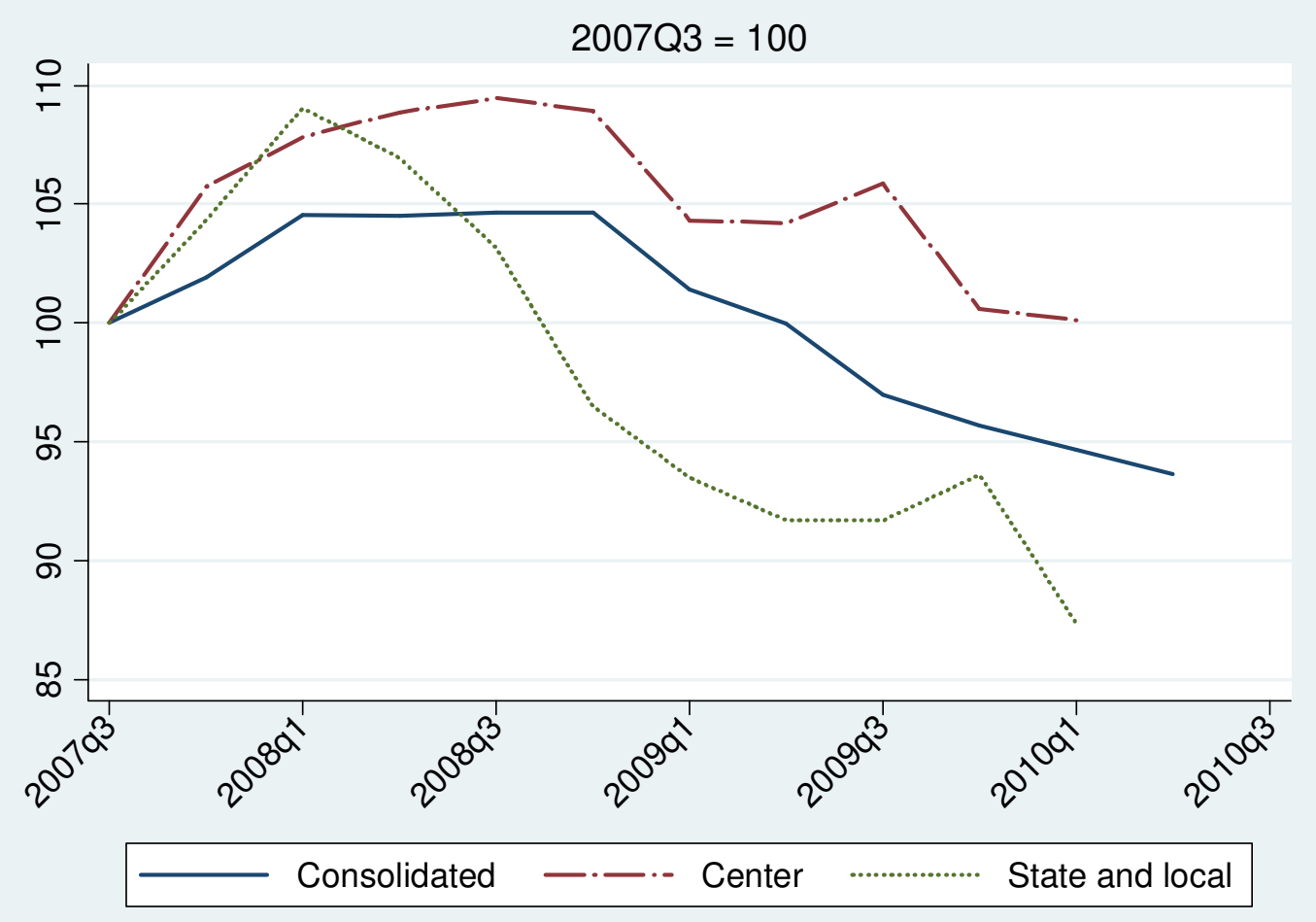

(c) Iceland

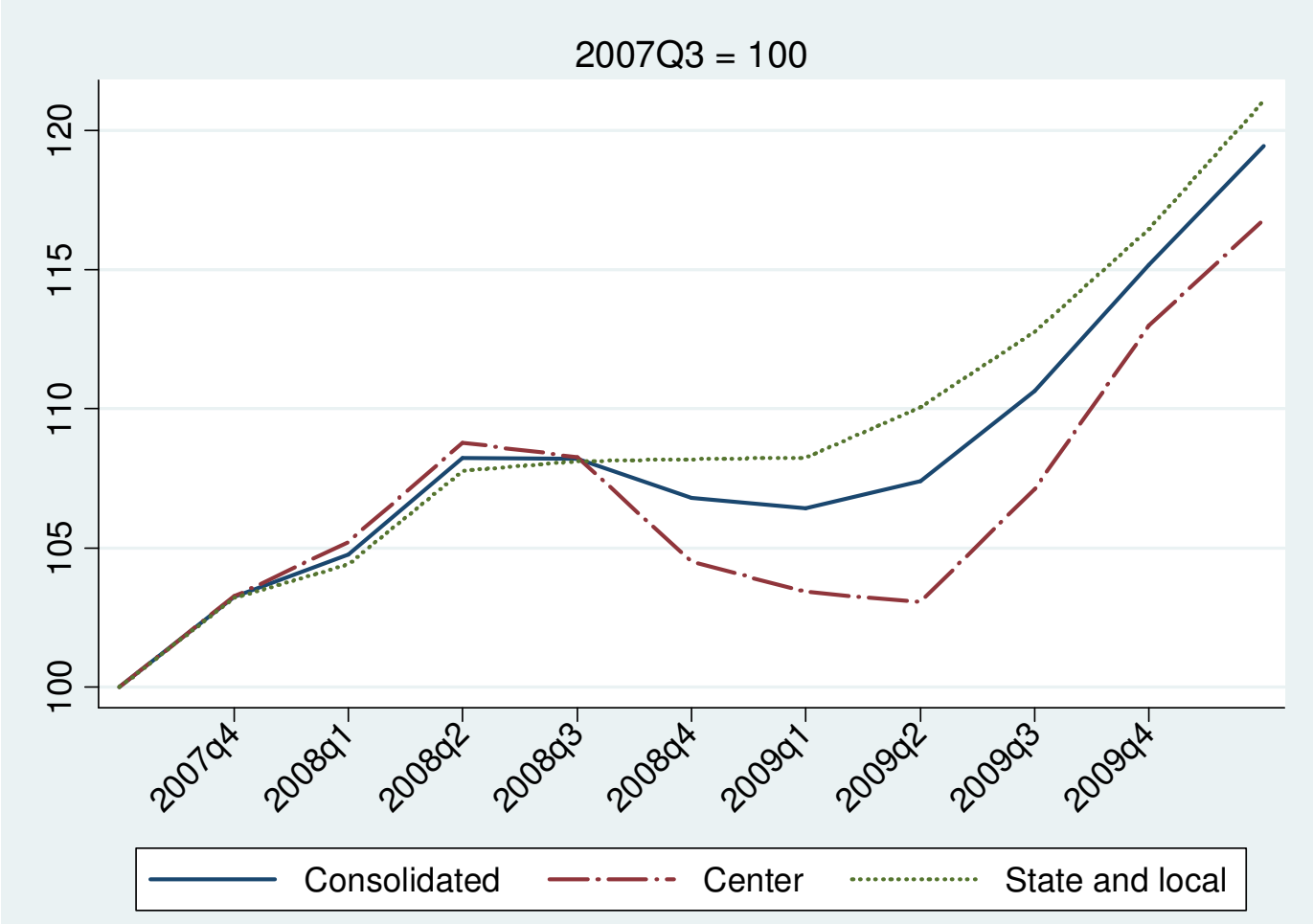


(d) Australia

Figure 10 (contd.): Pure fiscal expenditures, $\mathrm{C}+\mathrm{I}$, at each level of government

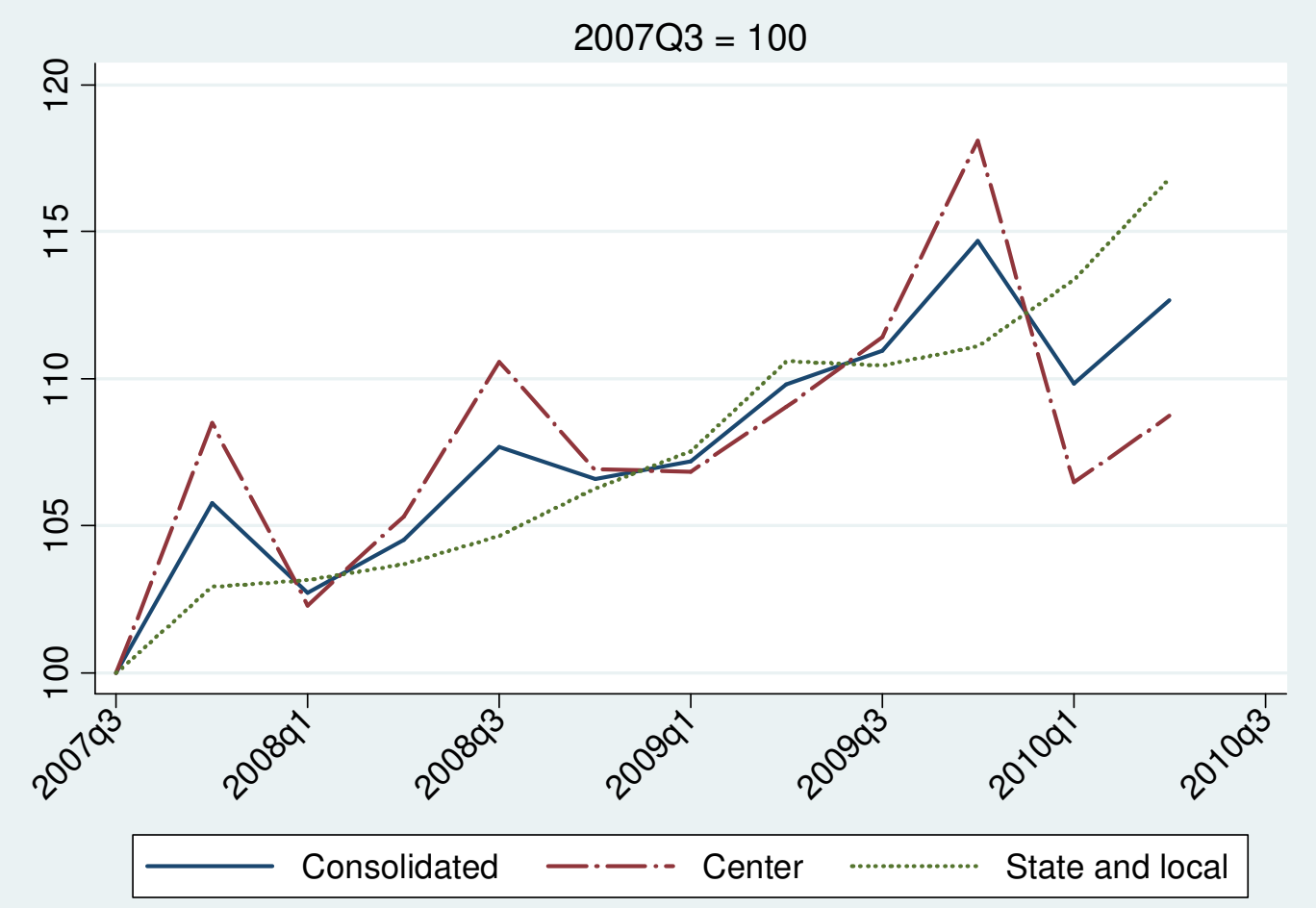

(e) Norway

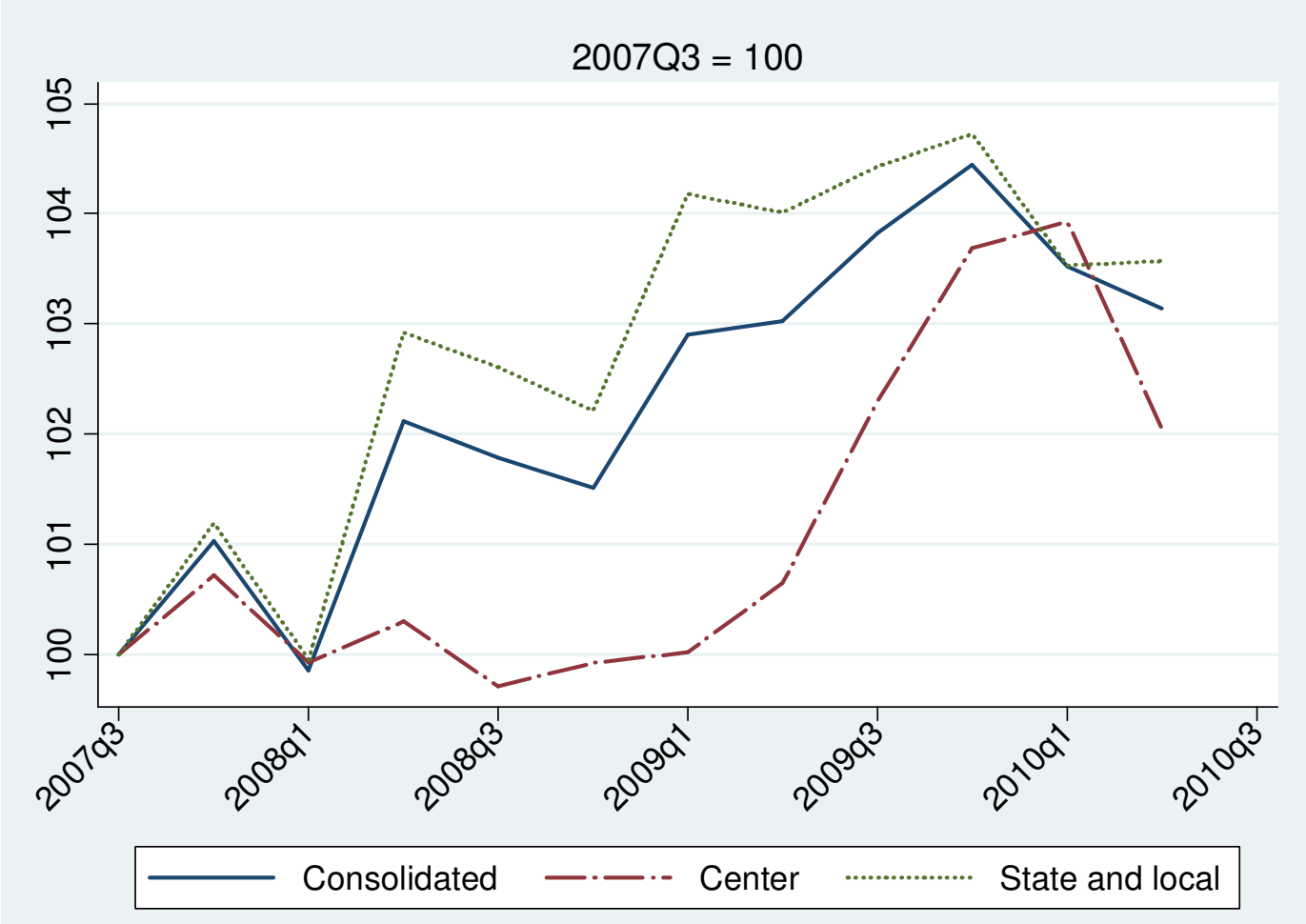




\section{(f) Sweden}

Figure 11: Over the period 2007Q4-2010Q1, state and local spending was pro-cyclical in US, Iceland and Australia, and countercyclical in Norway, Sweden and UK.

\section{Growth of government $C_{g}+I_{g}$ /growth of GDP}

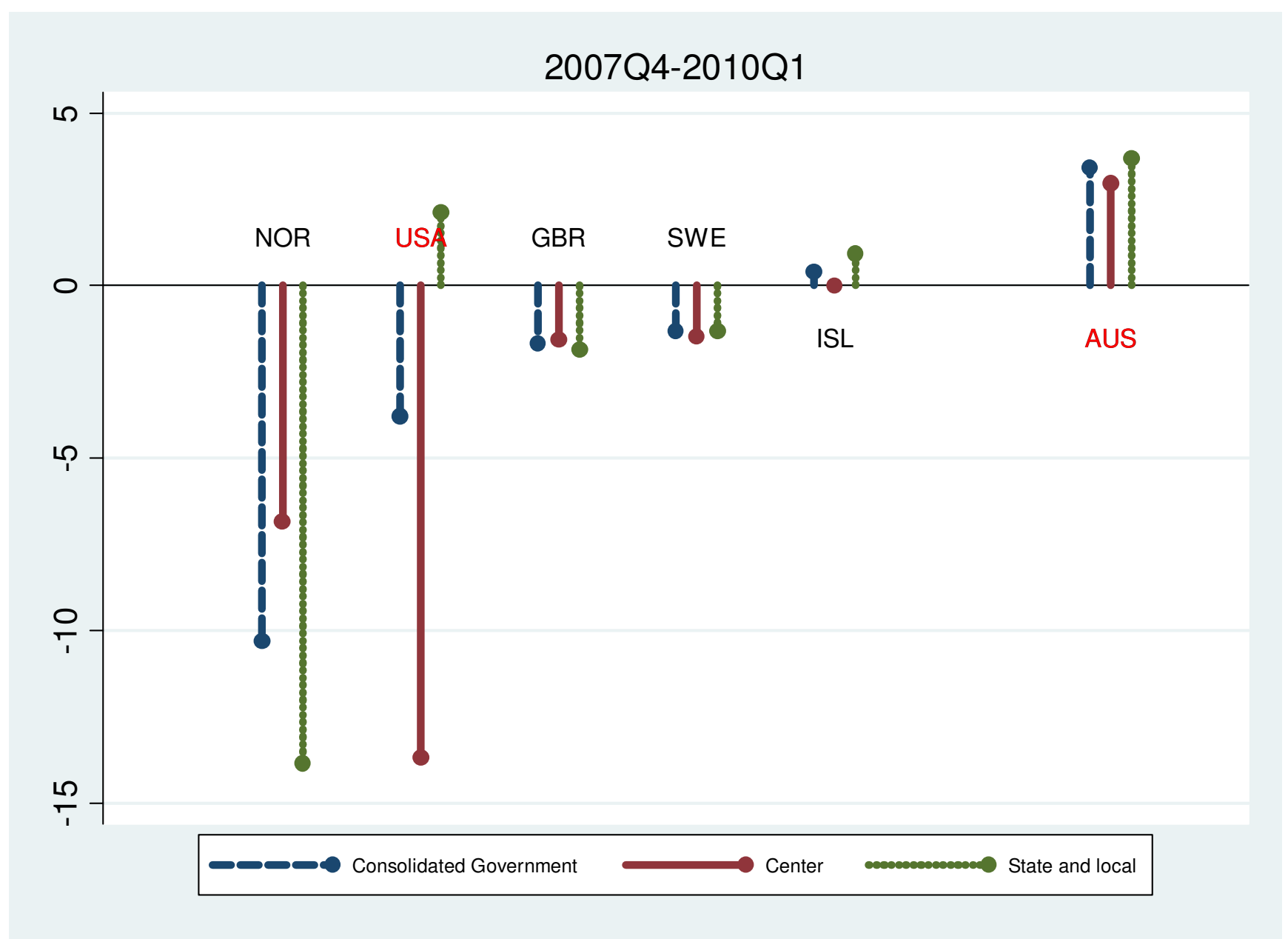

Note: The growth rates used to compute the ratio are the compound annual growth rates over the period. Negative values of the ratio indicate a counter-cyclical policy as it indicates that the government spending is contracting when GDP is increasing, and vice versa. In all countries except Australia, the GDP growth during this period was negative. Details of the data used in this graph are in Table 8. 
Figure 12: Stimulus efforts varied between countries. By 2010Q1, GDP in the USA was larger than its 2009Q1 level, but state and local pure fiscal expenditures were still falling. In UK, both central and state and local pure fiscal expenditures expanded as GDP fell over this period while in Norway, state and local expenditures increased while central expenditures fell.

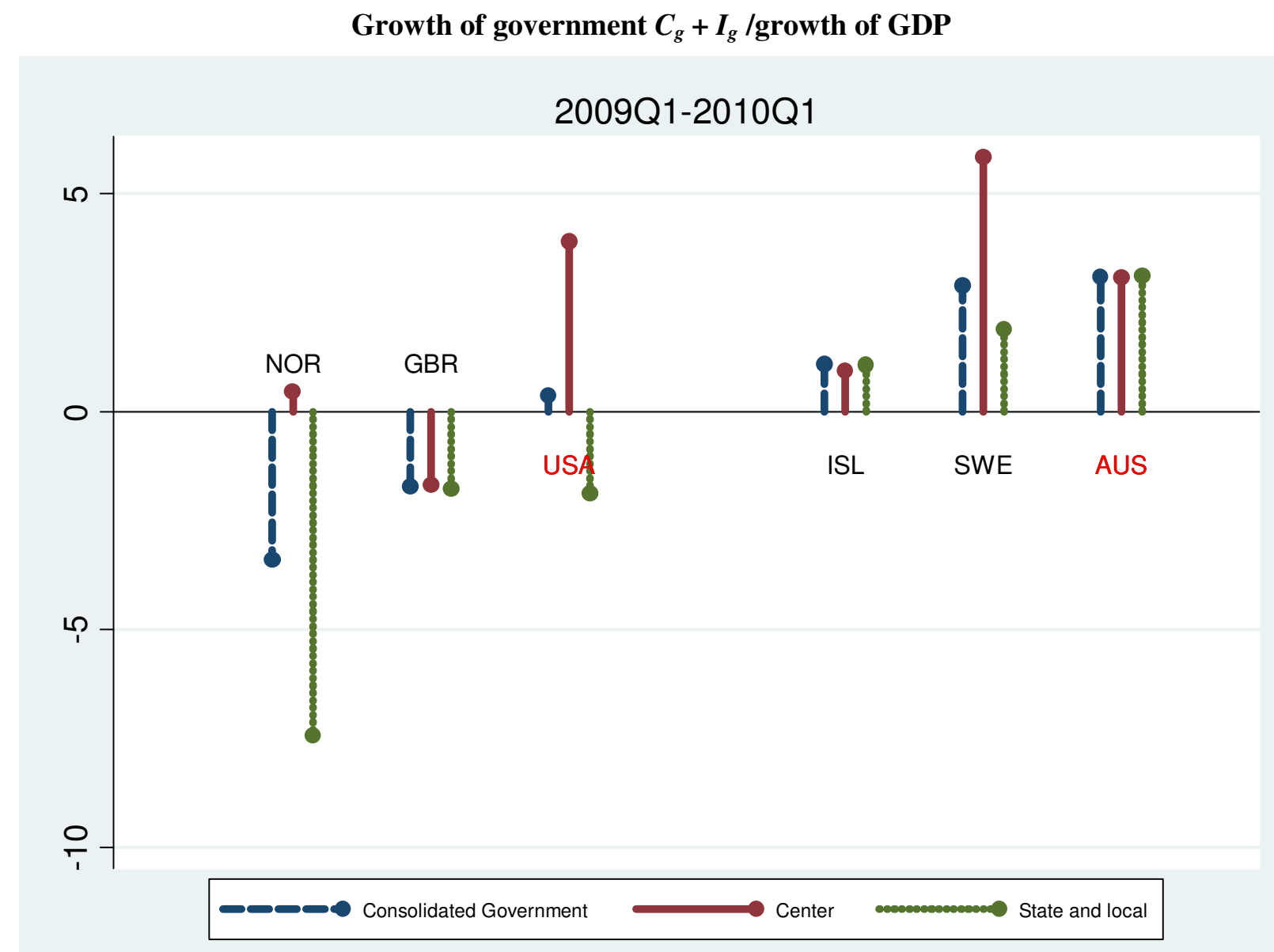

Note: The growth rates used to compute the ratio are the compound annual growth rates over the period. Negative values of the ratio indicate a counter-cyclical policy as it indicates that the government spending is contracting when GDP is increasing, and vice versa. In USA, Sweden and Australia, the GDP growth over this period was positive. Details of the data used in this graph are in Table 8. 


\section{Appendix:}

\section{Note on the treatment of financial and non-financial sector bailouts during the crisis.}

The infusions of money by the governments into financial or non-financial corporations during the crisis are not included in the consumption and investment expenditures of the government sector. Such transactions, whether they involve loans or acquisitions of equity, are included in the financial accounts of the government. They typically involve the exchange of one asset (for example, cash) for another (e.g.: equity or loan) and do not constitute spending. However, to the extent that the government provides a subsidy (for example, pays above the market price for equity), this subsidy is recorded in national income accounts as a capital transfer by the government. Again, since $C_{g}+I_{g}$ excludes capital transfers, these figures do not include the bailouts. However, all administrative costs of such transactions are recorded as usual in either compensation of employees or use of goods and services and are included in $C_{g}+I_{g}$.

The only exception to the above would be if the government ends up owning the enterprise fully and it is not classified as a 'public corporation', but as a government department. ${ }^{7}$ However, during this crisis, most interventions by governments were considered to be temporary and a decision was taken by the statistical authorities in the US, UK and EU to not include any such interventions in the national accounts, except to the extent described above. This may change in the future, for example if at some point, Fannie Mae and Freddie Mac become classified as part of the government sector.

For detailed discussions of the national income accounts and the treatments of financial bailouts in each of the above three regions, see the following documents:

\section{System of National Accounts:}

European Commission, International Monetary Fund, Organization for Economic Co-operation and Development, United Nations and World Bank. 2008. System of National Accounts.

\footnotetext{
${ }^{7}$ Accounts of public corporations are not included in government sector accounts.
} 


\section{Europe:}

European Commission. 2009. Eurostat Guidance Note: The statistical recording of public interventions to support financial institutions and financial markets during the financial crisis. European Commission. Eurostat: Decisions for GFS. (webpage link)

\section{UK:}

Office for National Statistics. 2009. News Release: The financial crisis and statistical classification decisions.

Office for National Statistics. 2009. Public Sector Interventions in the Financial Crisis:

Statistical Classification Decisions.

Office for National Statistics. 2009. UK National Accounts sector and transaction classification: A summary of the classification process.

Office for National Statistics. National Accounts Classifications. (webpage link)

\section{USA:}

Congressional Budget Office. 2009. The Treatment of Federal Receipts and Expenditures in the National Income and Product Accounts.

Bureau of Economic Analysis. 2009. GDP and the Economy: Advance Estimates for the Fourth Quarter of 2008. 
Table A1: Countries included in the high and low growth groups.

\begin{tabular}{|lc|ccc|}
\hline Country & $\begin{array}{c}\text { Country } \\
\text { name }\end{array}$ & $\begin{array}{c}\text { Average GDP per capita growth } \\
\text { during 2004Q1-2007Q1 }\end{array}$ & $\begin{array}{c}\text { High growth } \\
\text { group? }\end{array}$ & $\begin{array}{c}\text { Low growth } \\
\text { group? }\end{array}$ \\
\hline Australia & AUS & 1.52 & Yes \\
Austria & AUT & 2.79 & \\
Belgium & BEL & 2.14 & \\
Canada & CAN & 1.60 & \\
Chile & CHL & 4.45 & Yes \\
Czech Rep & CZE & 5.96 & Yes \\
Germany & DEU & 2.18 & \\
Denmark & DNK & 2.15 & \\
Spain & ESP & 1.68 & Yes \\
Finland & FIN & 3.90 & Yes & \\
France & FRA & 1.34 & & \\
U.K. & GBR & 1.88 & Yes \\
Greece & GRC & 3.54 & Yes \\
Hungary & HUN & 3.67 & Yes \\
Ireland & IRL & 2.69 & & \\
Iceland & ISL & 4.17 & Yes & \\
Italy & ITA & 0.67 & & \\
Japan & JPN & 2.12 & Yes & \\
Korea & KOR & 3.85 & & \\
Mexico & MEX & 1.58 & & \\
Netherlands & NLD & 2.70 & & \\
Norway & NOR & 1.46 & & \\
N. Zealand & NZL & 1.57 & & \\
Poland & POL & 5.38 & & \\
Portugal & PRT & 1.30 & & \\
Sweden & SWE & 3.59 & & \\
Turkey & TUR & 6.06 & & \\
U.S. & USA & 1.40 & & \\
No: & Yes & \\
\hline
\end{tabular}

Note: The average growth rate is the average over the period of the quarter -on-quarter growth rate. High growth group has countries whose average growth rate exceeded the $75^{\text {th }}$ percentile of growth rates across countries (all the rates in the table above). Low growth group includes countries whose average growth rate was below the $25^{\text {th }}$ percentile of the growth rates in the table above. 
Table A2: Data Sources

\begin{tabular}{|c|c|c|}
\hline Variable Name & Description & Sources \\
\hline $\begin{array}{l}G \\
\text { (or Consolidated } \\
\text { Government } \\
C_{g}+I_{g} \text { ) }\end{array}$ & $\begin{array}{l}\text { Consolidated Government real Consumption + } \\
\text { gross Investment expenditures in local currency } \\
\text { units. Seasonally Adjusted at Annual Rates. For } \\
\text { countries for which non-seasonally adjusted data } \\
\text { was available from the source, the C+I series was } \\
\text { adjusted for seasonality using Census X12 } \\
\text { method. As far as possible, the seasonal } \\
\text { adjustment was done after converting the series to } \\
\text { real terms. For conversion into real terms, where } \\
\text { possible, series specific deflators were used (e.g.: } \\
\text { government consumption deflator for government } \\
\text { consumption series and government GFCF } \\
\text { deflator for government investment series). When } \\
\text { separate C and I deflators for each level of } \\
\text { government were not available, government } \\
\text { consumption or government expenditure deflators } \\
\text { for the same level of government were used to } \\
\text { deflate C+I at each level of government. For the } \\
\text { central and state level data, general government } \\
\text { deflators were used if that was the only series } \\
\text { available. Finally, for countries for which none of } \\
\text { the government expenditure specific price } \\
\text { deflators were available, the GDP deflator was } \\
\text { used to convert the C+I series to real terms for } \\
\text { each level of government. }\end{array}$ & $\begin{array}{l}\text { National sources, OECD } \\
\text { Stat, Eurostat and IFS; } \\
\text { accessed through Thomson } \\
\text { Financial's Datastream and } \\
\text { DataInsight }\end{array}$ \\
\hline $\begin{array}{l}\mathrm{G}^{\mathrm{c}} \\
\text { (or Central } \\
\text { Government } \\
C_{g}+I_{g} \text { ) }\end{array}$ & $\begin{array}{l}\text { Central government real Consumption + gross } \\
\text { Investment expenditures in local currency units. } \\
\text { Seasonally adjusted at annual rates. }\end{array}$ & $\begin{array}{l}\text { National sources, OECD } \\
\text { Stat, Eurostat and IFS; } \\
\text { accessed through Thomson } \\
\text { Financial's Datastream and } \\
\text { DataInsight }\end{array}$ \\
\hline $\begin{array}{l}\mathrm{G}^{\mathrm{s}} \\
\text { (or State and Local } \\
\left.C_{g}+I_{g}\right)\end{array}$ & $\begin{array}{l}\text { State and local government real Consumption + } \\
\text { gross Investment expenditures in local currency } \\
\text { units. Seasonally adjusted at annual rates. }\end{array}$ & $\begin{array}{l}\text { National sources, OECD } \\
\text { Stat, Eurostat and IFS; } \\
\text { accessed through Thomson } \\
\text { Financial's Datastream and } \\
\text { DataInsight }\end{array}$ \\
\hline Recession Periods & $\begin{array}{l}\text { NBER recession quarters for the USA. For all } \\
\text { other countries, two or more consecutive quarters } \\
\text { of negative real GDP growth rate. }\end{array}$ & $\begin{array}{l}\text { National Bureau of } \\
\text { Economic Research and } \\
\text { Authors' calculations }\end{array}$ \\
\hline
\end{tabular}


Table A2 (contd). Data Sources

\begin{tabular}{|c|c|c|}
\hline Variable Name & Description & Sources \\
\hline$r$ & $\begin{array}{l}\text { Real interest rate (\% per annum) on general } \\
\text { government bonds of maturity closest to those } \\
\text { listed in appendix Table A3. Nominal interest } \\
\text { rates were converted into real rates by subtracting } \\
\text { the growth rate of GDP deflator. Real rates for } \\
\text { Austria are based on the average return on bonds } \\
\text { with maturities greater than one year for 1970- } \\
1982 \text {, and with a 9-10 year maturity for 1983- } \\
2010 \text {. }\end{array}$ & $\begin{array}{l}\text { BIS, OECD Stat, } \\
\text { Bloomberg, Datastream, } \\
\text { EuroStat, IFS and national } \\
\text { sources }\end{array}$ \\
\hline$g$ & year-on-year growth rate of real GDP $(\%)$ & $\begin{array}{l}\text { OECD Stat, Datastream, } \\
\text { IFS and national sources }\end{array}$ \\
\hline$d$ & Debt/GDP $(\%)$ for general government debt & $\begin{array}{l}\text { International Monetary } \\
\text { Fund's World Economic } \\
\text { Outlook }\end{array}$ \\
\hline
\end{tabular}

Note: IFS refers to International Monetary Fund's International Financial Statistics database. 
Table A3: Average effective debt maturity (years)

\begin{tabular}{|lc|}
\hline Country Name & Years \\
\hline Australia & 5.0 \\
Austria & 7.0 \\
Belgium & 6.0 \\
Canada & 6.0 \\
Chile* & 7.4 \\
Czech Republic & 6.4 \\
Denmark & 8.0 \\
Finland & 5.0 \\
France & 7.0 \\
Germany & 6.0 \\
Greece & 7.9 \\
Hungary & 3.0 \\
Iceland* & 13.0 \\
Ireland & 7.0 \\
Italy & 7.1 \\
Japan & 6.3 \\
Korea & 5.0 \\
Mexico* & 6.3 \\
Netherlands & 6.0 \\
New Zealand & 4.0 \\
Norway & 5.0 \\
Poland & 5.0 \\
Portugal & 6.0 \\
Spain & 7.0 \\
Turked* & 7.0 \\
United Kingdom & 3.6 \\
United States & 14.0 \\
Source: Bloomberg & 4.6 \\
\hline
\end{tabular}

Source: Bloomberg

*Average as of November 2010; all others as of July 2010 